\title{
Commodity price shocks, growth and structural transformation in low-income countries
}

\author{
Thomas McGregor* \\ Oxford Centre for the Analysis of Resource Rich Economies (OxCarre), Department of Economics, University of Oxford, United Kingdom
}

\section{A R T I C L E I N F O}

\section{Article history:}

Received 17 October 2016

Accepted 18 January 2017

Available online $\mathrm{xxx}$

\section{JEL classifications:}

011

013

L16

Q02

C01

C33

Keywords:

Dutch disease

Natural resources

Structural transformation

Panel-VAR

\begin{abstract}
A B S T R A C T
This paper uses a panel-VAR approach to estimate both the dynamic and structural macroeconomic response of resource-rich, low-income countries to global commodity price shocks. I use a block recursive ordering, as well as a simple Choleski decomposition, to identify structural commodity price shocks for a set of developing countries. The block recursive identification strategy assumes only that global macroeconomic conditions do not respond to individual low-income country conditions contemporaneously. The results suggest that a one standard deviation increase in commodity prices raises per capita income in developing countries by $0.26 \%$ and government spending and investment by $4.4 \%$ and $12.4 \%$. The effects are larger for less developed countries, economies with fixed exchange rate regimes and those that are more depended on commodity exports. Commodity price shocks also result in significant transformation of these economies, with the share of value-added in manufacturing contracting by $0.17-0.22$ percentage points. Whilst these effects may appear small, they represent the effect of exogenous commodity price shocks that are not due to changes in aggregate demand or global financial conditions. This suggests that commodity price movements alone may be less important in explaining the volatility of low-income country growth than other explanations. Taken together, these results present a more nuanced picture of the 'resource curse' in poor countries. Whilst per capital income levels are positively affected by resource booms, the potential for de-industrialisation does exist. The channel through which this link operates appears to be the real exchange rate, with resource booms leading to appreciation pressures. To illustrate the relevance of these results, I investigate the impact of the recent oil price collapse on the Nigerian economy.
\end{abstract}

(c) 2017 Board of Trustees of the University of Illinois. Published by Elsevier Inc. All rights reserved.

\section{Introduction}

The recent collapse of world commodity prices has led to some analysts calling this the end of the so called commodities 'super-cycle'. ${ }^{1}$ Diminishing growth prospects for emerging market economies, especially China, combined with abundant supply has continued to put downward pressure on the prices of most commodities, with the oil price reaching its lowest levels since the early 2000s according to the 2016 World Economic Outlook from the International Monetary Fund (IMF). The question of how resource booms and busts affect growth is as pertinent today as it has ever been, particularly for commodity exporting low-income countries.

\footnotetext{
* Correspondence to: Department of Economics, Manor Road Building, Oxford OX1 3UQ, United Kingdom.

E-mail address: thomas.mcgregor@economics.ox.ac.uk

1 The term commodities 'supercyle' is often defined as a decades-long, abovetrend movements in a wide range of base material prices (Erten and Ocampo, 2013; Heap 2005; Rogers 2004).
}

The empirical evidence on the effect of natural resource wealth on economic growth and development is mixed. Whilst some studies find that resource booms are a blessing, others find that they are a curse, and others still find that the outcome depends on a number of factors. ${ }^{2}$ Two key challenges have faced this literature from the start. The first, is that measures of resource wealth are likely to be endogenous to a whole host of economic and political factors. The second is that the channels through which any positive or negative economic impacts of a resource boom may operate are numerous and multifaceted. These include an appreciation in the real exchange rate, de-industrialisation, increased volatility, political patronage and rent-seeing, and violent conflict, to name but a few.

This paper aims to shed light on both these fronts. It develops a new proxy for resource wealth, based on subterranean reserves, that is exogenous to economic conditions in low-income countries. A panel vector auto-regression (panel-VAR) is used to orthogo-

\footnotetext{
2 See Van der Ploeg (2011) for a survey of the literature.
} 
nalise movements in the commodity prices, specifically minerals and hydrocarbons, against global and local economic conditions. The short-run macroeconomic response for low-income, resourcerich economies is investigated, as well as the de-industrialisation effects and a possible 'Dutch disease' channel.

Original work by Sachs and Warner $(1995,1999)$ finds a negative relationship between resource wealth and long-run economic growth, whilst more recent work by Mehlum, Moene, and Torvik (2006) finds that this is particularly the case in countries with poor institutions. This result continues to hold even after controlling for a whole host of potential omitted variables, as shown by Van der Ploeg (2011). Given the long time periods used, these findings can be thought of as the long-run relationship between resource booms and economic growth.

The key challenge facing this early work was the endogeneity of potential measures of resource wealth. The standard approach has been to use resource abundance (the share of resources in GNP) as the independent variable. However, this measure is likely to be endogenous for two reasons. First, by construction, dividing by GDP means that higher GDP will correlate with lower resources as a share of GDP thus setting up a negative correlation. Second, this scaling exercise implies that resource wealth as a share of GDP is no longer independent of the economic policies and institutions that drive both economic growth and the scale of resource production.

Controlling for this endogeneity results in the negative effect on growth coming into question. Brunnschweiler and Bulte (2008), for example, instrument for resource dependence, using resource abundance, constitutions, and institutions, and find that natural resource booms lead to higher growth. Van der Ploeg and Poelhekke (2010) use economically recoverable reserves as a proxy for resource wealth and find that there is no evidence for either a curse or a blessing, unless one allows for an indirect negative effect via volatility.

Another strand of the literature, which is similar in vein to this paper, focuses on the short-run effects of resource shocks on growth. Early work by Deaton and Miller (1996) finds a positive effect of commodity price booms on income levels in the Pan-Africa region using a vector auto-regression (VAR) framework. More recent work by Raddatz (2007) makes use of a panel-VAR to study the impact of different external shocks, including commodity price shocks, on output volatility in low-income countries. They find that positive commodity price shocks significantly raise income in the short run, but that these shocks in general can only explain a small fraction of the output variance of a typical lowincome country. In a slightly different approach, Collier and Goderis (2012) use a panel error correction model (ECM) to show that commodity booms have unconditional positive short-term effects on output, but potentially negative long-run effects in countries with poor governance.

These studies take similar approaches to addressing the endogeneity issues that have plagued the earlier growth literature. The approach is based on the work by Deaton and Miller (1996) who weight world commodity price indices by country specific commodity export shares in 1975, which are held constant over time. The authors argue that international commodity prices are typically unaffected by the economic conditions of individual countries and, as a result, can be treated as exogenous. Raddatz (2007) uses the same country specific commodity price indices whilst Collier and Goderis (2012) augment the indices by weighting them by the share of net commodity exports in GDP, which is also held constant. The validity of this approach hinges crucially on the exogeneity of these commodity price indices.

One concern is that commodity exports as a share of output may be correlated with unobservable characteristics in low income countries (Manzano \& Rigobon 2001). In addition, resource exports themselves may also be endogenous. Higher resource exports tend to be associated with fewer non-resource exports, less openness to trade and lower foreign direct investment. Van der Ploeg and Poelhekke (2010) argue that economically recoverable reserves are a more exogenous measure of resource wealth.

The first contribution of this paper is to construct an exogenous measure of resource wealth for low-income countries. The approach involves constructing measures of country specific commodity reserves which are then used to weight movements in global commodity price indices. By using reserves instead of exports, I argue that this new measure of resource wealth in low-income countries is more exogenous that those used in the literature to date.

Another concern is the assumed exogeneity of commodity prices and developing country economic conditions. Work by Hamilton (2003) and Kilian (2008) find that much of the increase in crude oil prices since the 1970 s, and particularity since 2002, has been due to increase in aggregate demand for all industrial commodities, rather than exogenous supply shocks. To the extent that global demand shocks may simultaneously affect both commodity prices and low-income country economic output, via export demand, foreign investment and capital flows, the endogeneity of commodity prices will be an issue.

Within the VAR literature, additional consideration must be given to the contemporaneous exogeneity assumptions imposed upon the system. Raddatz (2007), for example, imposes a lower triangular structure on the two blocks of the panel-VAR. The first block contains high income country GDP, commodity based termsof-trade, the international interest rate, and global disasters, with the second block containing low income country per capita GDP and aid flows. The key identifying assumption is that the flow of causality runs from rich country GDP to commodity prices to world interest rates, but not in reverse. However, this ignores the potential for monetary policy in rich countries to affect aggregate demand, as well as commodity prices.

The second contribution of this paper is to develop a framework that allows for the high degree of simultaneity between global demand, commodity prices and low-income country growth. To this end, the panel-VAR approach serves two purposes. First, it allows us to control for the interdependence between global economic conditions and low-income country growth. And second, by using a block recursive causal ordering, it allows for a greater degree of simultaneity within the global variables block and the local variables block. The results suggest that a one standard deviation increase in commodity prices (around $17.7 \%$ on average) raises per capita income levels in low-income countries by $0.26 \%$, government spending by $12.4 \%$ and investment by $4.4 \%$. The effects are larger for less developed countries, economies with fixed exchange rate regimes and those that are more dependent on commodity exports.

The final contribution of this paper is the investigation of the impact on the structure of the extracting economies following commodity price shocks. Specifically, I ask whether commodity price shocks lead to de-industrialisation in low-income, resourcerich countries. In an important contribution to the early literature, Corden and Neary (1982) formalised the de-industrialisation process that may result from resource booms. They distinguish between two channels: the 'resource movement' effect, which describes the process by which labour may be pulled out of the traditional manufacturing sector following a boom, and the 'spending effect', which describes the increase in demand for non-tradables following a boom. Using data from the UN on sectoral value added, I find that resource booms lead to significant de-industrialisation. A one standard deviation increase in commodity prices results in the share of value-added in manufacturing contracting by $0.17-0.22$ percentage points (pp), whilst transport and other non-tradable service sectors expand by around $0.10-0.13 \mathrm{pp}$ and $0.26 \mathrm{pp}$ recep- 
tively. This link appears to operate through the real exchange rate, with resource shocks leading to appreciations which in turn cause a restructuring of the domestic economy.

Whilst these effects may appear small, it is important to bear in mind that they represent the effect of exogenous commodity price shocks that are not due to changes in aggregate demand or global financial conditions. These estimates suggest that commodity price movements alone may be less important in explaining the volatility of low-income country growth than other explanations, such as demand and productivity shocks.

The focus on resource-rich, low-income countries is motivated on two fronts. The first, is that recent discoveries of potentially vast hydrocarbon reserves in sub-Saharan Africa ${ }^{3}$ makes the question of how commodity shocks affect growth and structural transformation in these countries highly pertinent. Second, low-income countries are often thought of as being highly susceptible to external shocks, particularly commodity price movements. Work by Collier and Gunning (1999), Dehn (2000) and Collier and Dehn (2001) have documented an important effect of commodity price shocks on growth in developing countries. Understanding both the dynamic and structural impacts these shocks have on low-income countries is vital.

The remainder of the paper is structured as follows. Section 2 presents the empirical methodology and the two step estimation procedure. Section 3 describes the construction of the reserve-weighted commodity price index used to identify exogenous commodity price shocks for each country. Section 4 describes the data. Sections 5 and 6 present the estimation results. Section 7 explores the Dutch disease mechanism. Section 8 uses these results to simulate the effect of recent oil price collapse on the Nigerian economy, and Section 9 concludes.

\section{Empirical methodology}

The main challenge in estimating the dynamic response of low-income, resource-rich economies to commodity price shocks is in identifying movements in commodity prices that are truly exogenous to economic conditions in these counties. Movements in global commodity prices will reflect both demand and supply shocks. Work by Hamilton (2003) and Kilian (2008) find that much of the increase in crude oil prices since the 70s, and particularity since 2002, has been due to increases in aggregate demand for all industrial commodities, rather than exogenous supply shocks. The problem is that movements in global aggregate demand, as well as international credit market conditions, are likely to simultaneously affect the economic conditions of low-income countries as well global commodity prices. In order to identify exogenous supply driven commodity price movements, I use a VAR model which orthogonalises the commodity price shocks against global aggregate demand and financial conditions.

The empirical approach consists of two steps. Given the interest in studying a group of low-income countries, the first step is to estimate a panel VAR. The VAR model should, in theory, isolate only supply driven changes in commodity prices (or demand driven price changes that do not immediately affect low-income economies) and therefore be exogenous from the perspective of

\footnotetext{
3 According to estimates by Wood Mackenzie, recoverable natural gas reserves in Mozambique are 85 trillian cubic feet (tcf) and 18 tcf in Tanzania, with another 100 tcf yet to be found; In Uganda, Tullow Oil estimate that recoverable oil reserves are 1.1 billion barrels (bb), with some 1.4 bb potentially yet to be found; in Madagascar, Madagascar Oil estimate recoverable oil reserves to be $1.7 \mathrm{bb}$, with a further 10.8 bb of oil and $167 \mathrm{tcf}$ of gas in undiscovered reserves according to an assessment by USGS; Ghana discovered 4 bb of oil in it's Jubilee field in 2007 and production is currently being scaled up; Kenya has also recently discovered potential oil and gas reserves.
}

low-income, resource-rich economies. The second step is to take these shocks and regress them on the various sectoral components of value added and operating surplus in these countries. The aim is to study both the aggregate macroeconomic response to commodity price shocks, as well as possible structural transformation processes that might take place as a result.

Clearly, the choice to focus on resource-rich, low-income countries is an important one. As discussed, it is motivated on two fronts: (i) recent discoveries of potentially vast hydrocarbon reserves in parts of the developing world, particularly sub-Saharan Africa, and (ii) low-income countries are often thought of as being highly susceptible to external shocks, particularly commodity price movements. Understanding both the dynamic and structural impact these shocks have on low-income countries is vital. However, by restricting the sample to low-income countries raises issues around selection bias. Namely, by focusing on poor countries today the empirical results may be biased towards finding a negative relationship between commodity price shocks and economic growth. For this reason, rather than using current income classifications, I select the sample of low-income countries using per capita GNI data from the World Bank in 1970.

\subsection{Structural panel VAR}

The first step involves estimating a structural vector autoregression (VAR) model on a panel dataset of macroeconomic variables of resource rich developing economies. ${ }^{4}$ Using a VAR approach allows all of the variables in the system to be endogenous. This is important, given the simultaneity in global economic conditions, commodity prices and poor countries' economic conditions. Applying it to panel data allows for unobserved heterogeneity.

Given that I am interested in estimating the dynamic macroeconomic response of natural resource shocks, the key challenge is in identifying exogenous structural shock series for each country. I do this in two ways. The first involves using a recursive causal ordering on the system, or a Choleski decomposition. Whilst this is a powerful method for identifying structural shocks in VAR models, it does come at the cost of imposing some prohibitively restrictive assumptions on the dynamics of the system. The second method uses a set of 'block recursive' type restrictions in which global macroeconomic variables are treated as a separate and independent block to the national variables, such as GDP, investment and government spending. Whilst I continue to impose contemporaneous exogeneity between the two blocks, I do not make any assumption about the causal ordering of variables within each block. This approach imposes much fewer restrictions on the system and is, for that reason, theoretically more appealing a priori.

I begin by describing the problem of identification of shocks in the panel VAR model. Consider, the following first order structural VAR (SVAR) model:

$\mathrm{Bx}_{\mathrm{i}, \mathrm{t}}=\Gamma_{0}+\Gamma_{1} \mathrm{x}_{1, \mathrm{t}-1}+\varepsilon_{\mathrm{i}, \mathrm{t}}$

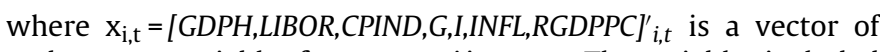
endogenous variables for country $i$ in year $t$. The variables included in the vector are: log changes in real GDP of high income countries $(G D P H)$, real US Libor rate (LIBOR), log changes in a GDP weighted commodity price index (CPIND) which will be discussed in more detail below, log changes in real government expenditure $(G), \log$ changes in real fixed capital formation, (or investment) (I), ${ }^{5}$ infla-

\footnotetext{
${ }^{4}$ I am grateful to Inessa Love and Lea Ziccino for the use of their panel VAR programme in Stata. See Love and Zicchino (2006).

$5 \mathrm{G}$ is General government final consumption expenditure (current US\$); I is Gross fixed capital formation (constant 2005 US\$). Both are taken from the World Bank's World Development Indicators.
} 
tion as measured by the GDP deflator index (INFL), and log changes in real GDP per capita ( $R G D P P C)$. The log changes specification for most of the variables is required to ensure stationarity in $\mathrm{x}_{\mathrm{i}, \mathrm{t}}$.

An identification problem arises when attempting to estimate Eq. (1). What is actually estimated when taking the model to the data is the following reduced form VAR (RVAR):

$\mathrm{x}_{\mathrm{i}, \mathrm{t}}=\mathrm{A}_{0}+\mathrm{A}_{1} \mathrm{x}_{\mathrm{i}, \mathrm{t}-1}+\mathrm{e}_{\mathrm{i}, \mathrm{t}}$

where $\mathrm{A}_{0}=\mathrm{B}^{-1} \Gamma_{0}, \mathrm{~A}_{1}=\mathrm{B}^{-1} \Gamma_{1}, \mathrm{e}_{\mathrm{i}, \mathrm{t}}=\mathrm{B}^{-1} \varepsilon_{\mathrm{i}, \mathrm{t}}, \mathrm{E}\left(\mathrm{ee}^{\prime}\right)=\Omega=\mathrm{B}^{-1} \Phi \mathrm{B}^{-1}$, and $\mathrm{E}\left(\varepsilon \varepsilon^{\prime}\right) \Phi=\mathrm{B} \Omega \mathrm{B}$. The immediate challenge in estimating Eq. (2) using panel data is that we are required to impose the restriction that the structure of the VAR, in particular the dynamics of the system, represented by the A matrices, are common across countries. This is a standard assumption in the literature (see Broda, 2001, 2004; Ahmed, 2003; Uribe \& Yue, 2006) because, given the length of the time series dimension of the data (around 29 years), it would not be possible to estimate country-specific dynamics. The implication is that the coefficient estimates in the $A_{0}$ and $A_{1}$ matrices are the same for each country. Since this assumption is likely not to hold in practice, I include country fixed effects $\mathrm{f}_{\mathrm{i}}$. The estimation equation becomes:

$x_{i, t}=A_{0}+A_{1} x_{i, t-1}+f_{i}+e_{i, t}$

Since the fixed effects are correlated with the regressors due to lags of the dependent variables, the standard fixed effects estimator will be biased. I therefore use forward mean-differencing, also referred to as the 'Helmert procedure' (see Arellano and Bover, 1995). This procedure removes only the forward mean, i.e. the mean of all the future observations available for each country-year. This transformation preserves the orthogonality between transformed variables and lagged regressors, so the lagged regressors can be used as instruments and estimate the coefficients by system GMM.

Whilst the estimates of the RVAR are consistent, it is not possible to recover the coefficients of the SVAR, which is the object of interest. The RVAR forces the contemporaneous structural shocks of each variable in $x_{i, t}$ into the errors $e_{i, t}$ which consists of some combination of the true structural shocks related to each variable $\varepsilon_{\mathrm{i}, \mathrm{t}}$. To isolate the structural shocks to any one of the variables in the system it is necessary to decompose the residuals in such a way that they become orthogonal.

\subsubsection{Choleski}

The first approach uses, is a simple recursive causal ordering, or a Choleski decomposition, of the $\mathrm{B}^{-1}$ matrix, which allows for the identification of the structural shocks $\varepsilon_{i, t}$ in the panel-VAR. Identification via a recursive causal ordering implies that the $\mathrm{B}^{-1}$ matrix linking the structural shocks and the reduced form errors is lower triangular.

$\left[\begin{array}{c}e_{G D P H_{t}} \\ e_{\text {LIBOR }_{t}} \\ e_{C P I N D_{i, t}} \\ e_{G_{i, t}} \\ e_{I_{i, t}} \\ e_{I N F L_{i, t}} \\ e_{R G D P P C_{i, t}}\end{array}\right]=\left[\begin{array}{ccc}1 & \cdots & 0 \\ \vdots & \ddots & \vdots \\ b_{71} & \cdots & 1\end{array}\right] \times\left[\begin{array}{c}\varepsilon_{G D P H_{t}} \\ \varepsilon_{L_{I B O R_{t}}} \\ \varepsilon_{C P I N D_{i, t}} \\ \varepsilon_{G_{i, t}} \\ \varepsilon_{I_{i, t}} \\ \varepsilon_{I N F L_{i, t}} \\ \varepsilon_{R G D P P C_{i, t}}\end{array}\right]$

where $\varepsilon_{\mathrm{xt}}$ is the vector of the structural shocks of interest from Eq. (1), $b_{i j}$ are the parameters of interest from the $B^{-1}$ matrix, and $\mathrm{e}_{\mathrm{xt}}$ are the reduced form errors from estimating the panel-VAR in Eq. (2). In using this approach, the ordering of the variables in $\mathrm{x}_{\mathrm{i}, \mathrm{t}}$ becomes important. The identifying assumption used in this case is that each variable in $x_{i, t}$ affects the variables that appear below it contemporaneously but only affects the variables above it with a lag. More specifically, it assumes that the contemporaneous causal order runs from the GDP of high income countries, to the US Libor rate, to the commodity price index for each country. The most endogenous variable is real per capita GDP in each country which is affected by all of the variables appearing before it in the VAR. This includes government spending and aggregate investment. This causal ordering means, for example, that the residual from the first equation of the RVAR, $e_{G D P H, t}$, contains only the orthogonalised shock of high income country GDP, $\varepsilon_{\mathrm{GDPH}, \mathrm{t}}$.

The ordering of the commodity price index (CPIND) after the global economic indicators (GDPH and LIBOR) means that commodity prices are assumed to only affect rich country GDP and the US Libor rate with a lag. Given, that this assumption is unlikely to hold in practice I explore an alternative identification strategy in the following section.

Placing CPIND before individual countries' economic indicators (G, I, INFL and RGDPPC) implies that commodity prices are not affected by the present economic performance of the lowincome country (government spending, investment, inflation and per capita GPD). This is the small country assumption. I appeal to two arguments in support of this assumption. First, none of the countries included in the sample are large enough exporters of any individual commodity to have an effect on global prices. ${ }^{6}$ And second, the construction of the commodity price index CPIND is such that any risk of contemporaneous correlation between it and national economic conditions is minimized. One concern is that current per capita GDP of the low income country may be affected directly by the level of exports (and commodity exports in particular). If commodity exports are used in the denominator of the weighted price index, as is often the case in studies of natural resource shocks, this would likely violate the contemporaneous homogeneity assumption of the commodity price index CPIND with respect to RGDPPC. The approach taken here is to use historical commodity deposits rather than current commodity exports to weight each price index. The construction of the commodity price index is discussed in detail in Section 3.

\subsubsection{Block recursive}

The second approach involves splitting the VAR into two blocks and applying the recursive causal ordering to the blocks, rather than the specific variables. This is known in the literature as 'block recursive' identification. The first block contains the global variables (GDPH, LIBOR and CPIND) whilst the second block contains the national variables (G, I, INFL and RGDPPC). The VAR model becomes:

$$
\left[\begin{array}{l}
e_{I} \\
e_{N}
\end{array}\right]=\left(\begin{array}{ll}
d_{11} & 0 \\
d_{21} & d_{22}
\end{array}\right) \times\left[\begin{array}{l}
\varepsilon_{I} \\
\varepsilon_{I}
\end{array}\right]
$$

where $e_{I}=\left[e_{G D P H_{t}}, e_{L_{L B O R_{t}}}, e_{C_{C I N D}}\right]$, is the vector of reduced form errors of the international variable block, and $e_{N}=$ $\left[e_{G_{i, t}}, e_{I_{i, t}}, e_{I N F L_{i, t}}, e_{R G D P P C},\right]$, is the vector of reduced form errors from the national block. The element $d_{11}$ is a $3 \times 3$ matrix of parameters to be estimated, whilst $\left[d, d_{22}\right]$ is a $4 \times 7$ matrix of parameters. Identification via a block recursive strategy implies that the $\mathrm{D}^{-1}$

\footnotetext{
6 The list of the 28 countries included in the panel is discussed in the data section and I believe that this assumption is likely to hold in the sample. No countries have been removed.
} 
matrix is lower triangular but the $\mathrm{B}^{-1}$ no longer is. Instead the zero restrictions are located in the upper right corner as follows:

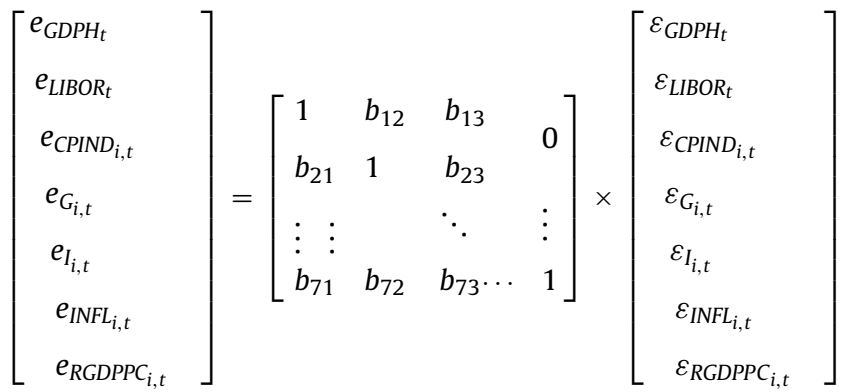

The identifying assumptions made here are less strict than those in the Choleski decomposition case in two ways. First, all of the national level variables are assumed to depend on each other contemporaneously. That is, I make no prior assumptions about which national level variables are pre-determined with respect to each other. And second, I allow the global variables, rich country GDP, the US Libor rate and the commodity price indices, to be contemporaneously inter-dependent with each other. The twelve zero restrictions in the top right corner of the B matrix are the sole restrictions placed on the system, namely that the three global level variables do not respond to the national level macroeconomic conditions contemporaneously. I justify the first eight restrictions $\left(b_{14}: b_{17}=0\right.$ and $b_{24}: b_{27}=0$ ) using the small country assumption, i.e. each individual country in the sample is not big enough to influence either global demand or global financial conditions. Given that I restrict the sample to low income countries, these restrictions seem plausible. The final four restrictions $\left(b_{34}: b_{37}=0\right)$ imply that the commodity price indices for each country in the sample do not react to national level economic conditions (specifically, national level GDP, investment, inflation and government spending). The same problems arise as in the Choleski identification strategy. Again, the construction of the price index will be important here.

It is worth noting that while the Choleski decomposition produces a unique solution for the $\mathrm{B}^{-1}$ matrix, the block recursive identification strategy does not. There are potentially an infinite number of rotations of the B matrix that would satisfy the zero restrictions placed on the block recursive model. The key, however, is that it is not possible to identify all of the structural shocks $\left(\varepsilon_{\mathrm{xt}}\right)$ under block recursion. In the current set-up however, it will be possible to identify the impact of individual shocks from one block on the variables of another. ${ }^{7}$ Specifically, the interest will be in identifying the impact of commodity price shocks (CPIND), which is located in the first block, on the national level variables (G, I, INFL, RGDPPC) in the second block.

Finally, the model in Eq. (3) is estimated using a single lag. The use of a single lag structure is done for ease of interpretation of the results, however, higher order lag structures, up to four lags, are also estimated, as are a number of lag-order selection statistics for the model. I find that one lag is a reasonable choice for this model.

\section{Seemingly unrelated panel regressions}

Having identified the structural commodity price shocks in the panel-VAR, the second step involves taking the orthogonalised commodity price error $\left(\varepsilon_{\mathrm{CPINDi}, \mathrm{t}}\right)$ and regressing these on the share of value-added in different sectors of the domestic economy. The

7 Satisfying the rank condition is key here. In an n-variable VAR, an equation is identified if and only if at least one non-zero determinant of order $(n-1)$ by $(n-1)$ can be constructed from the coefficients on the variables not excluded from that particular equation, when they appear in other equations in the model. I check the rank condition and find that it is satisfied. aim is to investigate the impact of commodity price shocks on the sectoral performance of low-income, resource-rich economies. The hypothesis is that, if a Dutch disease mechanism is at work, in which resource booms lead to a loss of international competitiveness, then these shocks, as proxied by shocks to the country specific commodity price index, should have a differential impact on the share of value-added in sectors that are more or less exportable. This follows from work by Rajan and Subramanian (2011) who find that aid inflows adversely affect manufacturing sectors that are more exportable and that this works through an appreciation of the real exchange rate.

I use a seemingly unrelated regression (SUR) framework which assumes that the error terms are correlated across equations. This is important as the residuals from the sectoral regressions are unlikely to be independent. I estimate the following model:

$$
\begin{aligned}
& y_{i, j, t}=\alpha+\beta_{1} G_{i, t}+\beta_{2} I_{i, t}+\beta_{3} I_{N F L} L_{i, t}+\beta_{4} R_{G D P P C}, t+\beta_{5} y_{-} i n i_{i, j, t} \\
& +\beta_{6} \text { CSHOCK }_{i, t}+f_{i}+n_{t}+\varepsilon_{i, j, t}
\end{aligned}
$$

where $G, I$, INFL and RGDPPC are defined as before, $y_{i, j, t}$ is the share of real value-added in sector $j$ of country $i$ at time $t$ in total real value-added, $y_{-} i n i_{i, j, t}$ is the initial share of real value-added, $f_{i}$ are country fixed effects, $n_{t}$ are year fixed effects, and $C S H O C K_{i, t}$ is the orthogonalised error $\left(\varepsilon_{C P I N D_{i, t}}\right)$ from the panel-VAR model for country $i$ at time $t$, scaled by the standard deviation of the shocks. Here, the structural error can be thought of directly as the exogenous component of commodity price shocks. The sign and size of the coefficient $\beta_{6}$ for each sector will highlight the existence or otherwise of potential de-industrialisation effects from positive commodity price shocks.

I exclude the global variables (GDPH and LIBOR) from the regression as these will be endogenous. Whilst this will also be the case for the local level variables (G, I, INFL and RGDPPC), I include these simply as controls as they will explain a large proportion of the variation in sectoral value added between countries. This should not be a concern, given that I am not making a causal interpretation of these coefficients, however I do check the robustness of the results to omitting all endogenous variables from the model (see Appendix A for details).

\section{Weighted price index}

The construction of the reserve-weighted commodity price index (CPIND) deserves further explanation. The aim is to construct a country specific commodity price index which measures the exposure of each low income country to movements in various global commodity prices, but which does not violate the contemporaneous exogeneity assumption between the commodity price index and national level variables $\left(b_{34}: b_{37}=0\right)$.

I construct an annual commodity price index ( $\left.\mathrm{PIND}_{\mathrm{c}, \mathrm{t}}\right)$ using UNCTAD commodity price data for nine minerals ${ }^{8}$ and EIA data for oil and gas prices, where $2010=100$. The analysis is restricted to minerals and hydrocarbons for a number of reasons.

First, much of the theory of the resource curse tends to focus on point resources. By focusing on minerals and hydrocarbons, this paper remains strictly within the realm of this existing theoretical work. In addition, the commodities I choose to focus on are predominantly windfall resources; that is, their discovery, excavation and exploitation is less endogenous to natural, political or economic conditions in the country. This is less likely to hold for a number of commodities, particularly agricultural products.

\footnotetext{
${ }^{8}$ These are: gold, silver, tungsten, iron, copper, lead, nickel, tin and zinc. Some organic sediments such as coal are not included in the UNCTAD monthly price series.
} 
Second, the resource curse theory emphasizes that the commodity sector is price-taking so that the effects of domestic demand do not feature in the analysis. This is important as it allows us to focus on the relative price challenge, i.e. the real exchange rate. Again, this would not be the case for many agricultural commodities which are subject to local and regional demand dynamics.

And finally, a key feature of the paper is the construction of an exogenous commodity index measure for each country. To do this, I make use of subterranean reserve data. Clearly the concept of reserves does not apply to many commodities, including agricultural products.

Changes in commodity prices may affect low income commodity exporters differently depending on the importance of these commodities in the economy. The problem with simply weighting the commodity price index by the share of that commodity in exports or GDP is that this scaling exercise implies that this variable is no longer independent of economic policies and institutions, and is potentially endogenous to domestic economic conditions. Instead, I construct a weight for each commodity, in each country, which is equal to the value of commodity reserves as a proportion of GDP in $1985 .{ }^{9}$ The key is that this 1985 reserve-GDP weight is independent of economic policy and institutions from 1985 onwards and is thus exogenous to local economic conditions. This weight is held constant over time and constructed as follows:

$w_{c, i}^{1985}=\frac{P_{c}^{1985} r_{c, i}^{1985}}{Y_{i}^{1985}}$

where $P_{c}^{1985}$ is the price of commodity $c$ in $1985, r_{c, i}^{1985}$ is the volume of reserves of commodity $c$ in country $i$ in 1985 , and $Y_{i}^{1985}$ is nominal GDP in country $i$ in 1985 . One problem with using 1985 reserves directly, is that the discovery of subterranean natural resources is likely to be endogenous to local economic and political conditions. New discoveries post-1985 are more likely to occur in countries that have favourable economic conditions. The risk is that, by ignoring these newly discovered reserves, we over-estimate the impact of commodity price shocks, which are weighted by reserves, on growth.

To deal with this, I construct an estimate of commodity reserves in each country in 1985 by summing up the annual production over the period and adding this to the 2013 estimate of sub-soil commodity reserves from the IntierrarRMG database. The definition of $r^{1985}$ is therefore given by:

$r_{c, i}^{1985}=r_{c, i}^{2013}+\sum_{t=1985}^{2013} y_{c, i}^{t}$

where $r_{c, i}^{2013}$ is the volume of reserves of commodity $c$ in country $i$ in 2013 , and $y_{c, i}^{t}$ is the production of commodity $c$ in country $i$ at time $t$. I then apply these weights to the annual price index pind ${ }_{c, t}$ for each commodity $(c)$ in each year $(t)$. This forms the 1985 reserve-GDP weighted commodity price index for each commodity produced in each country, which is summed over all commodities to produce a reserve-GDP country commodity price index $\left(\mathrm{CPIND}_{\mathrm{i}, \mathrm{t}}\right)$ as follows:

$\operatorname{CPIND}_{\mathrm{i}, \mathrm{t}}=\sum_{\mathrm{c}=1}^{13} \mathrm{w}_{\mathrm{c}, \mathrm{i}}^{1985}$ pind $_{\mathrm{c}, \mathrm{t}}$

This allows the effect of commodity price movements to be larger for countries in which commodities represent a larger share

\footnotetext{
9 The data I use comes from the IntierraRMG database on mining intelligence. The database includes annual production, at the mine level, from 1985 to 2013 as well as reserve data at the mine level for 2013. This means that the earliest I can construct reserve data for is 1985 .
}

of GDP, as measured by the size of their commodity reserves in 1985.

\section{Data}

\subsection{Sources}

The analysis in this paper makes use of data from a number of different sources: United Nations (UN) Statistics, United Nations Industrial Development Organisation's (UNIDO) INDSTAT2 database, UN Conference on Trade and Development (UNCTAD), International Monetary Fund (IMF) World Economic Outlook (WEO), IMF International Financial Statistics (IFS), World Bank (WB) World Development Indicators (WDI), The Penn World Tables 6.2 (PWT), The Natural Resource Governance Institute, US Energy Information Agency (EIA) and Intierrar-RMG.

I categorise a country as being resource-rich using the IMF's definition. According to the IMF, a country is defined as resource-rich if it has either natural resource revenue or exports at least $20 \%$ of total fiscal revenue or total exports, on average, over the period 2006-2010. ${ }^{10}$ There are 51 countries classified as resource rich. In addition, I add 12 countries who have recently discovered substantial natural resource reserves but where production may not yet have begun. ${ }^{11}$ I also include 9 countries where, according to the Natural Resources Governance Institute, minerals hold great potential for future fiscal revenue. ${ }^{12}$ This gives a total of 72 resource-rich countries.

I classify countries as low, middle or high-income using data on real GNI per capita using the World Bank Atlas method. Lowincome countries are those whose real GNI per capita in 1970 was below the equivalent of 1045 USD in the 2015 fiscal year. Of the 72 resource-rich countries, 46 are classified as low-income according to this definition.

Data on the sectoral breakdown of value added, employment and gross fixed capital formation comes from the United Nations (UN) database on National Accounts Estimates of Main Aggregates and UNIDO. The National Accounts data records the value added by industry according to International Standard Industrial Classification of All Economic Activities (ISIC), revision 4, 1-digit codes. The data is only available for the main groups and some categories are grouped together. The data covers 7 sectors $^{13}$ in 211 countries from 1970 to 2012.

Rich country GDP, which covers advanced economies ${ }^{14}$ only, as well as data on the US Libor rate and the US deflator, comes from the IMF's WEO database from 1980 to 2013. Data on the real exchange rate, inflation, population, T-bill rate, real per capita GDP in PPP terms for each low income country also comes from the WEO, also from 1980 to 2013.

\footnotetext{
${ }^{10}$ Gabon and Equatorial Guinea are included because of CEMAC monetary union membership; while Liberia, Niger, Cote d 'Ivoire and Uzbekistan are included in spite of incomplete data availability.

11 These are: Sierra Leone, Afghanistan, Madagascar, Mozambique, CAR, Uganda, Tanzania, Togo, Kyrgyz Re-public, Sao Tome and Principe, Ghana and Guatemala.

12 These are: Cambodia, Colombia, Egypt, India, Myanmar, Morocco, Philippines, South Sudan and Zimbabwe.

13 The sectors are: agriculture, hunting, forestry, fishing (ISIC A-B); mining, manufacturing, utilities (ISIC C- E); manufacturing (ISIC D); construction (ISIC F); wholesale, retail trade, restaurants and hotels (ISIC G-H); transport, storage and communication (ISIC I); other activities (ISIC J-P).

14 Composed of 35 countries: Australia, Austria, Belgium, Canada, Cyprus, Czech Republic, Denmark, Estonia, Finland, France, Germany, Greece, Hong Kong SAR, Iceland, Ireland, Israel, Italy, Japan, Korea, Luxembourg, Malta, Netherlands, New Zealand, Norway, Portugal, San Marino, Singapore, Slovak Republic, Slovenia, Spain, Sweden, Switzerland, Taiwan Province of China, United Kingdom, and United States.
} 
Purchasing power parity (PPP) conversion factors and nominal exchange rates for the calculation of the real exchange rate come from the Penn World Tables version 6.2.

Annual production of natural gas and oil comes from the US Energy Information Administration (EIA) and covers 208 countries from 1980 to 2013. The EIA also provides a time series of gas prices from 1922, and crude oil prices from 1986.

Data on individual mineral production and reserves comes from the IntierraRMG database on mining intelligence. The database includes annual production, at the mine level, from 1985 to 2013 as well as reserve data at the mine level for 2013. This data is aggregated up to the national level, and reserves in 1985 are calculated by adding the cumulative annual production to the reserves remaining in the ground in 2013, as discussed above.

I use commodity price data from UNCTAD from 1960 to $2013 .{ }^{15}$ The minerals for which I have production, reserves and prices for are: gold, silver, platinum, palladium, aluminium, iron, copper, lead, nickel, tin, zinc, diamonds and tungsten. ${ }^{16}$

\subsection{Summary statistics}

I use the full sample of low-income, resource-rich countries in the sample, for which there is sufficient data. Of the original 46 countries, 16 are dropped from the analysis due to lack of data. Table 1 provides a summary of the data. Of the 30 remaining countries, half are in Sub-Saharan Africa, 8 are in Latin America or the Caribbean, 4 are in North Africa or the Middle East and 3 are in Asia (East or South). The majority, 12, are LMICs today (according to their per capital GNI in 2013), with 8 UMICs and 2 HICs. 8 of the countries remain LICs today.

The first thing to note is that the majority of countries in the sample are no longer low-income countries. That is to say, many of the resource-rich countries who were poor in 1970 have in fact managed to foster sufficient economic growth to move themselves out of low-income country status. Clearly, the countries that have grown faster over the period are now richer, as is reflected in the average growth rates by income group. However, those countries that have remained poor have not only grown at a slower pace over the period, but this growth has been much more volatile than any other group. Second, the countries that have remained poor have also experienced the largest declines in government expenditure on average. Those that have managed to achieve middle-income country status have seen government expenditure fall by far less over the period. Only the high-income country group have had positive growth in government expenditure. Finally, it would appear that the low growth rates observed in low-income countries do not appear to have been due to low levels of investment. Investment, as measured by the growth in real fixed capital formation, has actually been relatively high in the low-income country group at around $7.1 \%$ per annum on average. However, this investment has been extremely volatile over the period.

The monthly evolution of commodity prices over the period 1960-2013 for the nine mineral commodities, plus oil, ${ }^{17}$ used in this paper is given in Fig. 1. The first thing to note is the significant amount of volatility in each of the series over the time period. Second, there appear to be three periods in which the commodity price series' display common shocks. These are around 1980, 1990 and 2008, all of which correspond to major global economic crises. It is important that, when using commodity prices as a proxy for

\footnotetext{
15 Price data for palladium and platinum are not available from UNCTAD so I use data from the RMG database instead.

16 The diamond price is calculated by dividing production quantity by production value-thus specific to each country.

17 I do not have monthly prices for natural gas, only annual prices.
}

commodity shocks, these potentially demand driven movements in commodity prices are dealt with appropriately.

\section{Panel-VAR estimation results}

This section presents the results from estimating the panel-VAR model in Eq. (3). The model is estimated using annual data for the 30 low-income, resource-rich countries in the dataset, covering the period 1985-2013. The average number of years for which data exists for each country is 24 , giving 704 observations in total. The model in Eq. (1) could be estimated using OLS, however, as discussed in Section 2, given the inclusion of fixed effects and a lagged dependent variable, common dynamic panel bias becomes a problem (Nickell, 1981). ${ }^{18}$ To overcome this problem, I estimate the coefficients by system GMM using forward-mean differencing. Given the use of some observations (and their lags) as instruments in the GMM estimation the sample size is reduced slightly to 643 .

The following two figures present the IRFs for various shocks identified using the Choleski and block recursive strategies. Only selected IRFs are presented here and confidence intervals are left out for ease of viewing. Note however, that all of these IRFs are statistically significant at the $5 \%$ level or better. ${ }^{19}$ As most of the variables in the model are in log differences, the IRFs show the log changes in each variable. The IRFs are scaled by the standard deviation of the shocks, and so they represent responses of variables to shocks of the order of magnitude seen in the data. Each panel plots the dynamic response of one variable to a one standard deviation shock in another.

In interpreting these results, it is worth bearing in mind that, if the identifying restrictions hold, these IRFs plot the dynamic response of each variable in the system to an exogenous shock, or impulse, of each variable.

\subsection{Choleski}

Fig. 2 presents the orthogonalised and cumulative impulse response functions (IRFs) from the applying the Choleski decomposition. Panel (a) shows the own IRF for the country specific reserve-GDP weighted commodity price index (CPIND). It plots the time profile of a one-period, one standard deviation increase in the commodity price index (just over $17.7 \%$ on average). We see that the bulk of the effect of shocks on the price of commodities produced by low-income, resource-rich, countries tend to last no more than one year on average.

Panels (b) and (c) show the dynamic response of the commodity price index (CPIND) to a one standard deviation impulse to advanced economy real GDP (GDPH) and the US Libor rate (LIBOR) respectively. These two panels correspond to the dynamic response of commodity prices to shocks in aggregate global demand and global financial conditions. As expected, a one standard deviation increase in global aggregate demand (or around $4.2 \%$ ), leads to an immediate and statistically significant increase of the average commodity price index for low-income countries of around 1.5 standard deviations. The dynamic response of commodity prices to global demand shocks lasts for around 3 years. A one standard deviation

\footnotetext{
18 While it is true that the bias in dynamic panels approach zero as $\mathrm{T}$ becomes large, Judson and Owen (1999) find significant bias even when T = 30. In my dataset, I have 24 years of data on average for each country.

19 The IRFs from the Choleski model with 95\% confidence bands, before scaling, are presented in Appendix A (Fig. 12). The confidence bands are generated by Monte Carlo simulation with 10,000 simulations. The process involves randomly generate a draw of coefficients of $A_{0}$ and $A_{1}$ from Eq. (2) using the estimated coefficients and their variance-covariance matrix and re-calculate the impulse- responses. This process is repeated 100 times and the 5th and 95th percentiles of the distribution of coefficients are used to generate the confidence interval for the IRFs.
} 
Table 1

Summary statistics.

\begin{tabular}{|c|c|c|c|c|c|c|c|c|c|c|c|c|c|c|c|c|c|c|c|c|c|c|c|c|}
\hline \multirow[t]{2}{*}{ Country } & \multirow[t]{2}{*}{ Region } & \multirow{2}{*}{\multicolumn{2}{|c|}{2013 Income group }} & \multirow[b]{2}{*}{$\mathrm{N}$} & \multirow[b]{2}{*}{ Min } & \multirow[b]{2}{*}{ Max } & \multicolumn{2}{|c|}{$\begin{array}{l}\text { Real per capita } \\
\text { GDP growth }\end{array}$} & \multicolumn{2}{|c|}{$\begin{array}{l}\text { Commodity price } \\
\text { index growth }\end{array}$} & \multicolumn{2}{|c|}{ Gov exp growth } & \multicolumn{2}{|c|}{$\begin{array}{l}\text { Real fixed capital } \\
\text { formation growth }\end{array}$} & \multicolumn{2}{|l|}{ GDP deflator } & \multicolumn{2}{|c|}{$\begin{array}{l}\text { Manufacturing real } \\
\text { value-added share }\end{array}$} & \multicolumn{2}{|c|}{$\begin{array}{l}\text { Agriculture real } \\
\text { value-added share }\end{array}$} & \multicolumn{2}{|c|}{$\begin{array}{l}\text { Growth in manuf } \\
\text { rva share }\end{array}$} & \multicolumn{2}{|c|}{ Growth in agric rv } \\
\hline & & & & & & & Mean & SD & Mean & SD & Mean & SD & Mean & SD & Mean & SD & Mean & SD & Mean & SD & Mean & SD & Mean & SD \\
\hline Indonesia & EAP & LIC & & 28 & 1986 & 2013 & 0.036 & 0.041 & 0.053 & 0.128 & -0.036 & 0.332 & 0.061 & 0.113 & 12.252 & 13.138 & 24.610 & 2.744 & 14.365 & 2.403 & 0.012 & 0.021 & -0.022 & 0.035 \\
\hline Philippines & EAP & LMIC & & 28 & 1986 & 2013 & 0.020 & 0.023 & 0.053 & 0.128 & 0.025 & 0.114 & 0.051 & 0.081 & 6.937 & 4.461 & 24.365 & 1.210 & 13.315 & 1.640 & -0.004 & 0.018 & -0.018 & 0.027 \\
\hline Bolivia & LAC & LMIC & & 27 & 1986 & 2012 & 0.015 & 0.019 & 0.061 & 0.128 & -0.058 & 0.317 & 0.057 & 0.121 & 17.209 & 42.845 & 13.719 & 0.301 & 13.828 & 1.094 & 0.003 & 0.020 & -0.010 & 0.033 \\
\hline Chile & LAC & HIC & & 28 & 1986 & 2013 & 0.039 & 0.026 & 0.053 & 0.128 & 0.010 & 0.097 & 0.084 & 0.10 & 9.484 & 7.602 & 16.192 & 1.577 & 3.704 & 0.329 & -0.008 & 0.022 & 0.007 & 0.040 \\
\hline Colombia & LAC & UMIC & & 13 & 2001 & 2013 & 0.027 & 0.017 & 0.045 & 0.350 & 0.050 & 0.106 & 0.095 & 0.052 & 5.352 & 1.772 & 14.632 & 0.973 & 7.876 & 0.7 & -0.012 & 0.028 & -0.017 & 0.020 \\
\hline Ecuador & LAC & UMIC & & 28 & 1986 & 2013 & 0.012 & 0.026 & 0.048 & 0.263 & 0.030 & 0.087 & 0.038 & 0.092 & 3.274 & 10.231 & 12.414 & 3.218 & 9.419 & 0.758 & 0.011 & 0.116 & 0.009 & 0.044 \\
\hline Guatemala & LAC & LMIC & & 28 & 1986 & 2013 & 0.011 & 0.013 & 0.053 & 0.128 & -0.019 & 0.201 & 0.043 & 0.089 & 10.362 & 10.530 & 20.660 & 2.061 & 13.373 & 0.923 & -0.011 & 0.010 & -0.006 & 0.015 \\
\hline Mexico & LAC & UMIC & & 28 & 1986 & 2013 & 0.009 & 0.031 & 0.053 & 0.128 & -0.105 & 0.282 & 0.033 & 0.096 & 23.189 & 32.909 & 17.011 & 0.921 & 3.513 & 0.338 & 0.001 & 0.023 & -0.011 & 0.038 \\
\hline Peru & LAC & UMIC & & 28 & 1986 & 2013 & 0.020 & 0.057 & 0.053 & 0.128 & -0.405 & 1.017 & 0.089 & 0.173 & 356.014 & 1163.234 & 17.167 & 0.750 & 6.927 & 0.632 & 0.001 & 0.034 & 0.004 & 0.054 \\
\hline Trinidad And Tobago & LAC & HIC & & 18 & 1991 & 2008 & 0.046 & 0.039 & 0.082 & 0.217 & 0.016 & 0.104 & 0.066 & 0.278 & 7.069 & 7.187 & 17.651 & 3.867 & 1.075 & 0.507 & 0.036 & 0.040 & -0.089 & 0.123 \\
\hline Algeria & MENA & & & 24 & & & & 0.029 & 0.046 & 0.117 & -0.089 & 0.234 & 0.022 & 0.08 & 13.938 & 13.622 & & & & & -0.016 & & 0.022 & 0.094 \\
\hline Egypt & MENA & LMIC & & 28 & 1986 & 2013 & 0.024 & 0.016 & 0.053 & 0.128 & -0.041 & 0.12 & 0.0 & 0.1 & 10.7 & & 15.652 & & 14.6 & & & & & .014 \\
\hline Iran & MENA & UMIC & & 19 & 1986 & 2007 & 0.014 & 0.057 & 0.067 & 0.268 & -0.158 & 0.204 & 0.032 & 0.112 & 20.460 & 7.972 & 8.320 & 2.099 & 9.898 & 0.731 & 0.049 & .045 & 0.004 & 0.057 \\
\hline Morocco & MENA & LMIC & & 27 & 1986 & 2012 & 0.023 & 0.045 & 0.061 & 0.123 & 0.050 & 0.060 & 0.047 & 0.053 & 3.245 & 3.207 & 16.363 & 1.413 & 16.483 & 3.039 & -0.011 & 0.054 & -0.010 & 0.220 \\
\hline India & $\mathrm{SA}$ & LIC & & 28 & 1986 & 2013 & 0.044 & 0.023 & 0.053 & 0.129 & 0.005 & 0.095 & 0.077 & 0.062 & 7.255 & 2.551 & 15.444 & 0.720 & 23.560 & 6.532 & 0.003 & 0.030 & -0.032 & 0.036 \\
\hline Botswana & SSA & UMIC & & 27 & 1986 & 2012 & 0.037 & 0.044 & 0.061 & 0.123 & -0.002 & 0.137 & 0.080 & 0.089 & 9.600 & 5.410 & 6.394 & 0.902 & 2.964 & 0.839 & 0.017 & 0.084 & -0.030 & 0.115 \\
\hline Cameroon & SSA & LMIC & & 27 & 1986 & 2012 & -0.011 & 0.040 & 0.050 & 0.267 & 0.027 & 0.227 & 0.015 & 0.133 & 3.200 & 4.414 & 18.265 & 0.856 & 19.852 & 1.866 & 0.001 & 0.033 & 0.016 & 0.041 \\
\hline Cote d'Ivoire & SSA & LMIC & & 20 & 1986 & 2005 & -0.013 & 0.029 & 0.017 & 0.101 & -0.020 & 0.269 & -0.013 & 0.135 & 4.133 & 10.631 & 15.726 & 1.149 & 26.211 & 1.090 & 0.013 & 0.063 & 0.001 & 0.046 \\
\hline DRC & & & & 16 & & 2009 & -0.017 & & & & -1.089 & & & & 962.317 & 6645.197 & 21.475 & & & & & & & 0.048 \\
\hline Gabon & SSA & & & 22 & & & -0.009 & & & & -0.024 & & -0.010 & & 5.275 & 14.703 & & & & & & & 001 & 0.093 \\
\hline Liberia & SSA & LIC & & 12 & 2001 & 2012 & 0.042 & 0.162 & 0.131 & 0.246 & 0.084 & 0.385 & 0.024 & 0.539 & 8.059 & 8.334 & 5.561 & 0.903 & 71.173 & 4.038 & 0.239 & 791 & -0.002 & 0.039 \\
\hline Madagascar & SSA & LIC & & 24 & 1986 & 2009 & -0.007 & 0.047 & 0.046 & 0.372 & -0.082 & 0.301 & 0.070 & 0.22 & 14.788 & 9.989 & 13.963 & 0.520 & 28.981 & 1.348 & -0.002 & 0.038 & 0.000 & 0.038 \\
\hline Mali & SSA & LIC & & 27 & 1986 & 2012 & 0.018 & 0.035 & & 0.123 & 0.039 & 0.3 & & 0.25 & 4.031 & 7.180 & 9.279 & 1.768 & 41.858 & & -0.013 & 0.123 & 0.003 & 0.077 \\
\hline Mauritania & SSA & LMIC & & 14 & 1999 & 201 & & 0.047 & 0.1 & 0.10 & 0.006 & 0.1 & & 0.3 & 6.594 & 8.181 & 8.523 & 1.990 & 30.5 & & -0.008 & 0.161 & -0.019 & 0.063 \\
\hline Mozambique & SSA & LIC & & 27 & 1986 & 2012 & & 0.042 & 0.002 & 0.273 & -0.175 & 0.465 & 0.087 & 0.14 & 28.382 & 36.820 & 12.545 & 2.995 & 29.055 & & 0.000 & 0.096 & -0.008 & 0.067 \\
\hline Nigeria & $\begin{array}{l}\text { SSA } \\
\text { SSA }\end{array}$ & LMIC & & 8 & 2006 & 2013 & 0.034 & 0.014 & 0.083 & 0.246 & 0.062 & 0.237 & 0.130 & 0.255 & 19.638 & 34.567 & 7.191 & 1.007 & 25.080 & 0.7 & 0.051 & 0.056 & $\begin{array}{l}-0.007 \\
-0.007\end{array}$ & 0.020 \\
\hline Rep Cong & & LMIC & & 26 & 1986 & 2011 & -0.004 & & & & & & & & & & & & 4.612 & & & & 0.004 & 0.052 \\
\hline Sierra Le & SSA & LIC & & 24 & 19 & 20 & & 0.0 & & & -0.2 & & & & & 42. & 2.952 & & & & -0. & & 0.005 & 0.018 \\
\hline Sudan & SSA & LMIC & & 23 & 198 & 20 & & 0.0 & 0.0 & 0.1 & -0.259 & & & & & 43. & & & 36. & & & & & .091 \\
\hline Zambia & SSA & LMIC & & 28 & 1986 & 2013 & 0.005 & 0.038 & & 0.128 & -0.243 & 0.440 & & 0.172 & & 42.328 & 10.631 & 0.679 & 22.065 & 3.367 & -0.004 & 0.054 & 0.000 & 0.149 \\
\hline Total & & & & 705 & 1986 & 2013 & 0.017 & 0.047 & 0.055 & 0.187 & -0.084 & 0.474 & 0.059 & 0.242 & 71.795 & 1039.664 & 13.342 & 6.210 & 18.018 & 14.180 & 0.007 & 0.123 & -0.007 & 0.078 \\
\hline \multirow[t]{2}{*}{2013 Income group } & & \multicolumn{2}{|c|}{$\begin{array}{l}\text { Real per capita } \\
\text { GDP growth }\end{array}$} & & $\begin{array}{l}\text { mmodit } \\
\text { dex grov }\end{array}$ & price & Gove & p growth & & $\begin{array}{l}\text { Real fixe } \\
\text { formatio }\end{array}$ & $\begin{array}{l}\text { d capital } \\
\text { in growth }\end{array}$ & & DP deflator & & $\begin{array}{l}\text { Manu } \\
\text { value- }\end{array}$ & $\begin{array}{l}\text { Ifacturing real } \\
\text {-added share }\end{array}$ & & $\begin{array}{l}\text { griculture } \\
\text { alue-adde }\end{array}$ & $\begin{array}{l}\text { eal } \\
\text { share }\end{array}$ & $\begin{array}{l}\text { Growth } \\
\text { rva shat }\end{array}$ & $\begin{array}{l}\text { in manuf } \\
\text { re }\end{array}$ & & $\begin{array}{l}\text { Growth i } \\
\text { share }\end{array}$ & \\
\hline & $\mathrm{N}$ & Mean & SD & & ean & SD & Mean & SD & & Mean & SD & & Iean & SD & Mean & SD & & Iean & SD & Mean & SD & & Mean & SD \\
\hline LIC & 186 & & 0.05 & & & & & & & & 0.30 & & & 845.694 & 13.225 & 1.623 & & & 3.50 & 0.025 & 0.15 & & & 0.0 \\
\hline LMIC & 284 & 0.0 & 0.0 & & & & & 0.2 & & 0.0 & & & & & 13. & 1.15 & & 12 & 1.8 & $0 . c$ & 0.056 & & & 0.064 \\
\hline UMIC & 189 & 0.014 & 0.041 & & 052 & 0.205 & -0.08 & 0.2 & 292 & 0.048 & 0.122 & & 54.638 & 156.232 & 10.66 & 1.375 & & 6.698 & 0.705 & 0.008 & 0.059 & & -0.002 & 0.064 \\
\hline HIC & 46 & 0.043 & 0.033 & & 068 & 0.172 & 0.01 & & 101 & 0.075 & 0.190 & & 8.277 & 7.394 & 16.922 & 2.722 & & 2.390 & 0.418 & 0.014 & 0.031 & & -0.041 & 0.082 \\
\hline
\end{tabular}



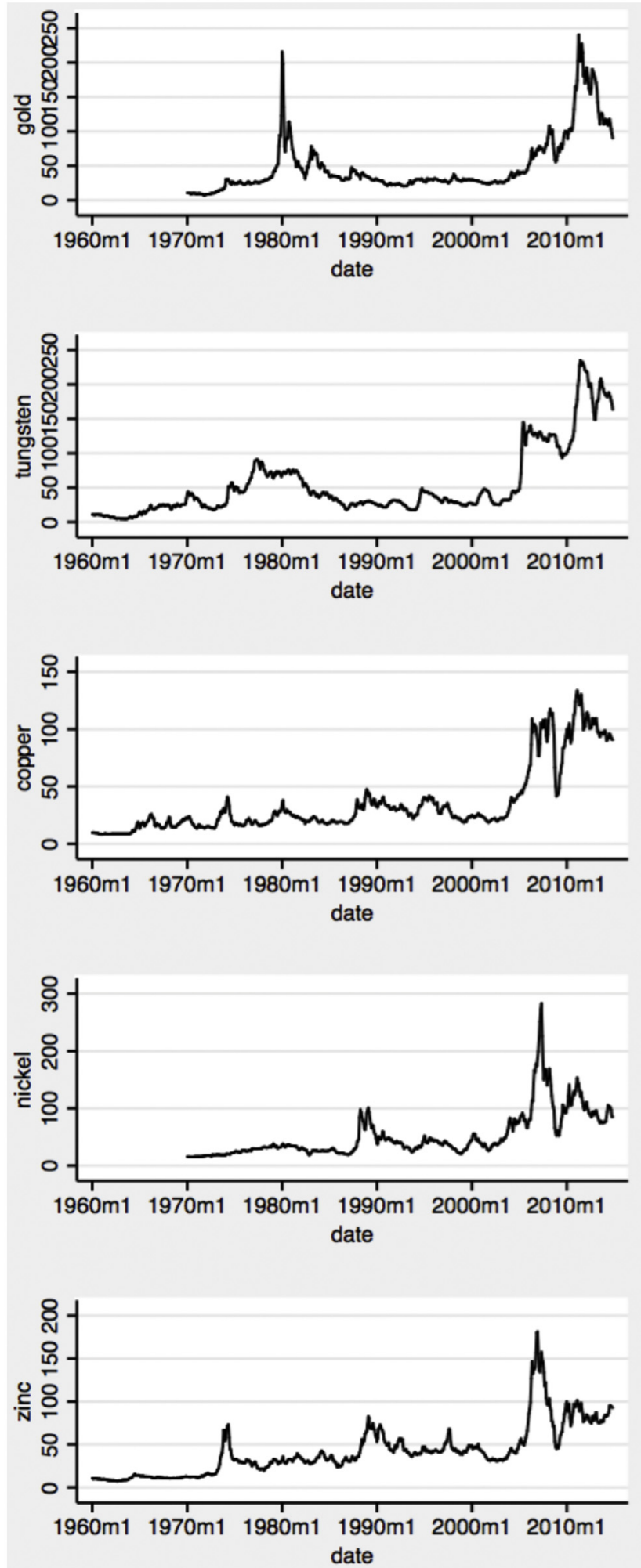
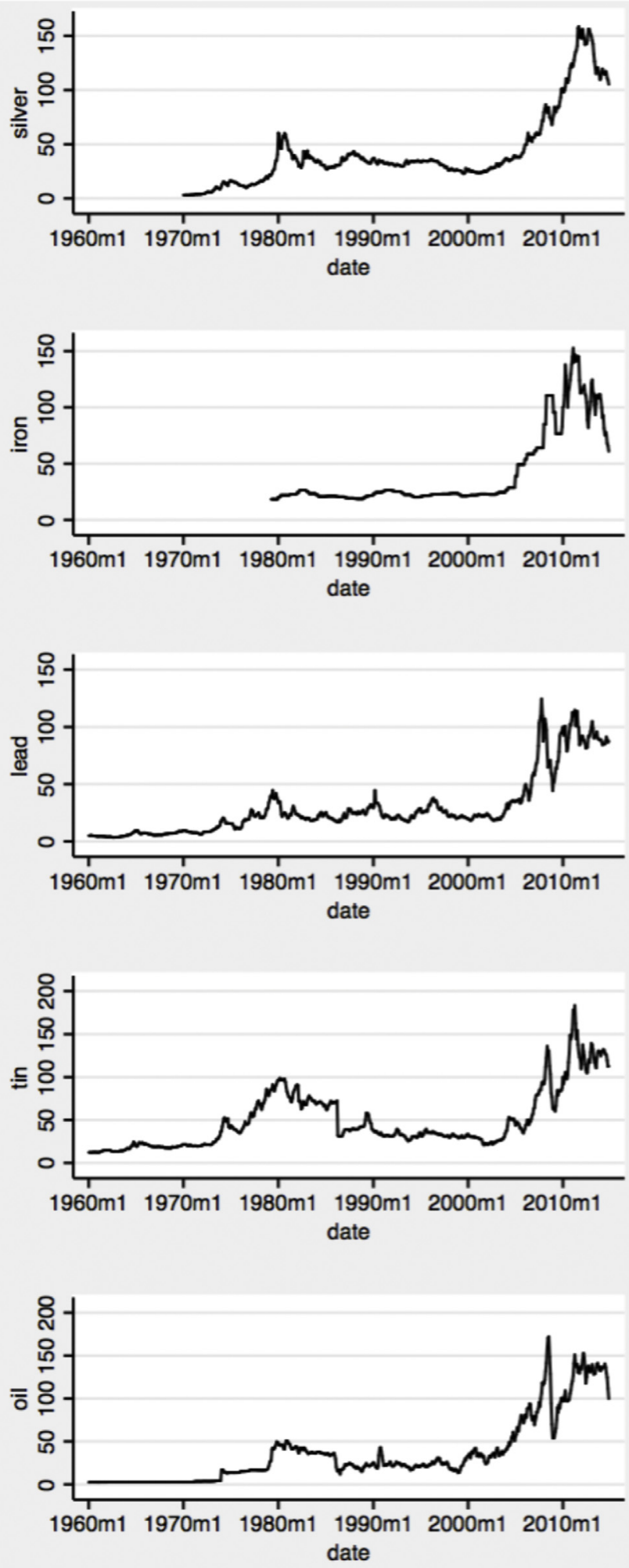

Fig. 1. World commodity prices.

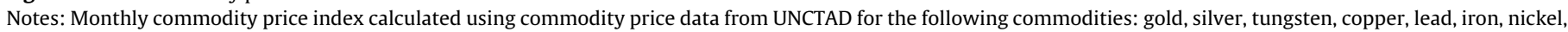
tin, zinc and oil. Monthly price index for gas not available.

shock to the 3-month US Libor rate (or an increase of around 1.25 percentage points), which proxies for the actual cost of borrowing for LICs, leads to an immediate fall in commodity prices of 0.024 standard deviations. This is likely due to the fact that in normal times, the US Libor rate will move with the Federal Funds rate.
Any positive shock to this rate will result in lower demand holding supply constant, and so lower commodity prices.

Panel (d) shows the response of real per capita GDP (RGDPPC) to a shock in the commodity price index (CPIND). A one standard deviation increase in the commodity price index results in an increase in real per capita GDP in the following period of around 0.043 standard 
(a) imp: cpind - resp: cpind

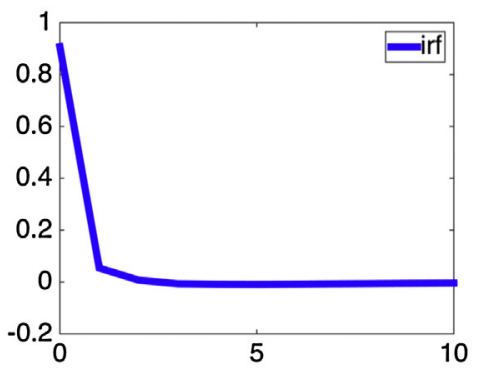

(d) imp: cpind - resp: rgdppc

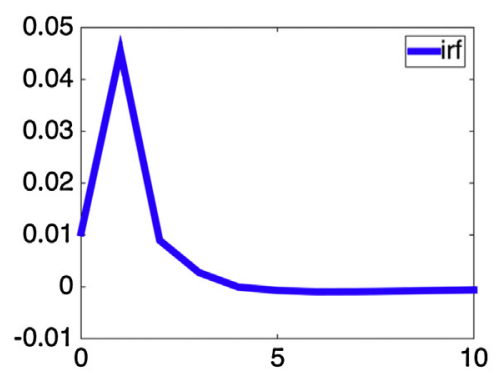

(b) imp: gdph - resp: cpind

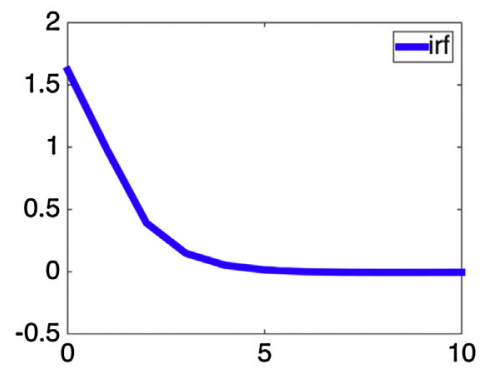

(e) imp: cpind - resp: g

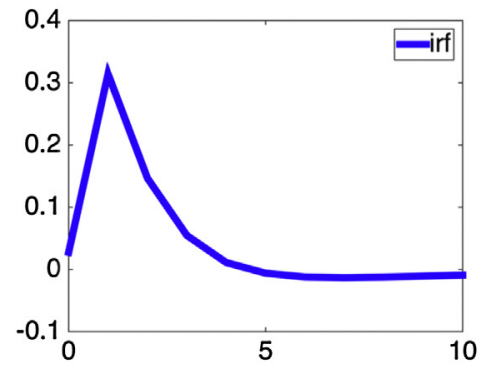

(c) imp: libor - resp: cpind

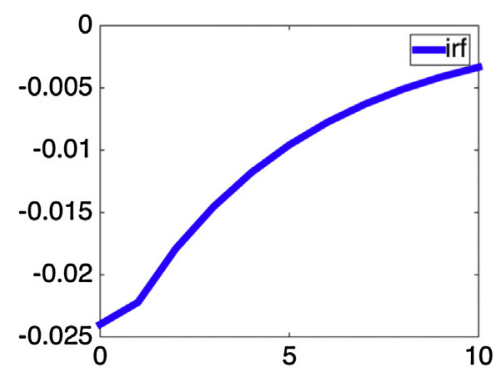

(f) imp: cpind - resp: i

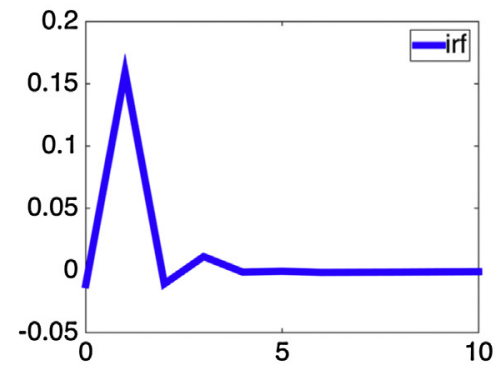

Fig. 2. Panel VAR IRFs-Choleski identification strategy.

deviations. Given that the average standard deviation of income growth is $4.3 \%$, this response is equivalent to an increase in real GDP per capita of around $0.18 \%$. Growth remains above its baseline level for around two to three years following a commodity price shock, before returning to the pre-shock level.

This is a relatively small effect. It suggests that commodity price movements alone may be less important in explaining the volatility of low-income country growth than other explanations. These could include demand, productivity and climatic shocks, international financial flows and conflict episodes.

The remaining panels, (e) and (f), show the response of government spending $(G)$ and fixed investment $(I)$ to the same commodity price shock. We see that the commodity price shock results in higher government expenditure and investment growth. ${ }^{20}$ From panel (e) we see that a one standard deviation increase in CPIND results in a statistically significant increase in real government expenditure $(G)$ of around 0.3 standard deviations (or 9.3\%) in the following period. Government expenditure remains above its baseline level for at least 4 years following a commodity price shock. Finally, from panel (f) we see that the same commodity price shock results in an increase in real capital formation ( $I$ ) of around 0.15 standard deviations (or 2.9\%). Investment then returns quickly to its baseline level in year 2, but remains volatile as a result for at least four years.

\subsection{Block recursive}

Fig. 3 presents the IRFs using the block recursive restrictions rather than Choleski to retrieve the structural shocks to the panelVAR system. As discussed in the methodology section, given the nature of the identifying restrictions placed on the model, it is not possible to retrieve all of the structural errors from the panel-VAR. Here, I focus on the response of national level variables, which

${ }^{20}$ The average standard deviation of the residual is $31.0 \%$ from the G equation, and $19.3 \%$ from the I equation. appear in the second block, to shocks to the commodity price index, which appears in the first block.

I continue to scale the response functions by the standard deviations in the data. The results suggest that whilst both identification strategies broadly agree on the direction of the IRFs, the block recursive strategy delivers larger response functions for real income, government spending and investment in low-income countries. Given the more plausible restrictions placed on the $\mathrm{B}^{-1}$ matrix under block recursiveness, the difference in the IRFs is evidence that the simple recursive ordering approach underestimates the impact of commodity price movements on macroeconomic conditions in resource rich, low-income countries.

Panel (a) of Fig. 3 shows that, under block recursion, a one standard deviation shock to commodity prices leads to an immediate increase in per capita GDP growth of around 0.06 standard deviations, equivalent to $0.26 \%$. This is larger than under Choleski and is due to commodity shocks now being stripped of any endogeneity with respect to global economic conditions.

Panels (b) and (c) of Fig. 3 show the response of government spending $(G)$ and fixed investment $(I)$ to a commodity price shock under block recursiveness. The direction of the IRFs are all in agreement with the results from the Choleski identification strategy, and the magnitudes of the responses are all larger. From panel (d) we see that a commodity price shock results in a statistically significant increase in real government expenditure $(G)$ of 0.4 standard deviations (or 12.4\%) in the following period, compared to 0.3 under Choleski. From panel (e) we see that the same commodity price shock results in an increase in real capital formation $(I)$ of around 0.23 standard deviations (or $4.4 \%$ ), compared to 0.15 under Choleski.

\subsection{Robustness}

One concern may be the inclusion of OPEC members in the analysis who are likely to set their oil production levels strategically in 
(a) imp: cpind - resp: rgdppc

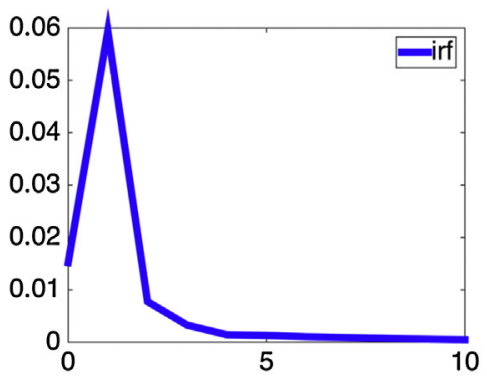

(b) imp: cpind - resp: g

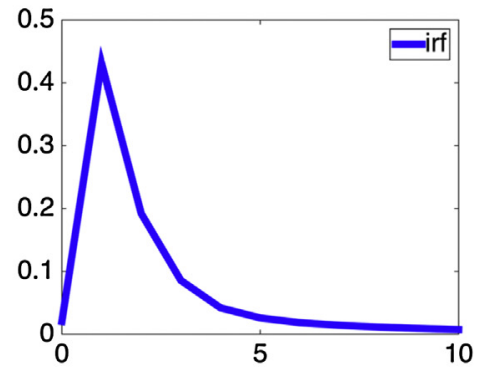

(c) imp: cpind - resp: i

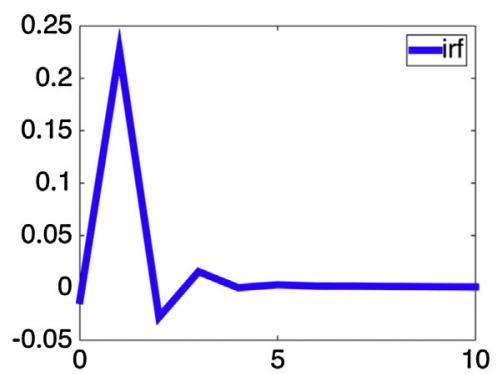

Fig. 3. Panel VAR IRFs-block recursive identification strategy.

response to the oil price. ${ }^{21}$ I therefore re-estimate the IRFs without OPEC members. The results are presented in Figs. 4 and 5 in Appendix A. The impact of CPIND shocks on real income growth fall slightly under both identification strategies; from 0.043 to 0.038 under Choleski, and from 0.06 to 0.042 under block. The impact on government spending and investment are also reduced. The intuition here is that OPEC members may be more able to guide the oil market to their collective advantage, resulting in more beneficial effects of commodity price movements on local economic conditions.

Another interesting experiment is to test the sensitivity of the headline results to restricting the sample to low income countries. I re-run the panel-VAR estimations on an extended sample which includes middle-income, resource-rich countries. ${ }^{22}$ The results are presented in Figs. 6 and 7 in Appendix A. The IRFs under Choleski present broadly the same picture in this extended sample (see Fig. 6). Under the block restrictions, the impacts of commodity price shocks on local variables are again reduced. The impact of commodity price shocks on real income falls from 0.06 standard deviations to 0.04 (see Fig. 7), whilst the impacts on government spending and investment also fall to 0.3 and 0.15 respectively. On one hand we might expect more developed economies to be better placed to take advantage of resource windfalls. On the other hand, however, the effect of commodity windfalls is likely to be diluted in more developed countries, whose economies are less dependent on resource exports.

Standard macroeconomic theory suggests that the choice of exchange rate regime is important for the ability of an economy to respond to external shocks. Flexible exchange rates allow for a faster adjustment to real shocks whilst fixed exchange rates insulate the domestic economy from monetary shocks. Under a flexible exchange rate regime for example, a rise in a countries terms of trade would typically lead to an expansion in aggregate demand, putting upward pressure on the interest rate and causing capital inflows. This in turn would lead to an appreciation in the exchange rate and a reduction in net exports, thus mitigating the effects of the initial shock. Under fixed exchange rates the economic impacts of real shocks are magnified. I test this prediction using our panel VAR. In Figs. 8 and 9 I classify countries as fixed or flexible exchange rate regimes respectively and estimate the impulse response func-

\footnotetext{
21 The recent revival of OPEC discussions following the low oil price is an example of coordinated action by members in an attempt to guide the oil market. The OPEC members included in the dataset are: Algeria, Ecuador, Gabon, Indonesia, Iran, Nigeria and Saudi Arabia; although Gabon, Ecuador and Indonesia all suspended the membership at some point over the period from 1985 to 2013.

22 The World Bank classifies countries as middle income if GNI per capita in 2015 is between $\$ 1,025$ and $\$ 12,475$. The countries added to the analysis are: Kyrgyz Republic, Lao PDR, Mongolia, Norway, Sao Tome and Principe, South Sudan, TimorLeste, Uzbekistan, Venezuela, Vietnam, Yemen, Albania, Angola, Azerbaijan, Iraq, Khazakstan, Suriname, Turkmenistan.
}

tions separately. ${ }^{23}$ The results support the theory. I find that the response of real income, to commodity price shocks, whilst continuing to be short lived, are magnified under fixed exchange rates, by up to four times on average. A similar result exists for government spending and investment.

Finally, I explore the link between countries' exposure to commodity price shocks and the magnitude of the dynamic responses of macroeconomic variables to these shocks. We may expect the size of the IRFs to depend on the importance of commodity exports to each economy. In effect, countries with larger resource exports should have larger IRFs. I investigate this by splitting the sample of countries into two groups: (i) those with no natural resource exports in 2013 and (ii) those with positive levels of resource exports in 2013. I exclude countries which had extremely large resource exports in 2013, specifically above \$US10 million. ${ }^{24}$ I compare the magnitude of the response of real per capita GDP growth to shocks in the commodity price index. The results, reported in Figs. 10 and 11 in Appendix A, appear to offer some support to this hypothesis. This is particularly visible in the block recursive IRFs presented in Fig. 11 where the size of the response of real GDP per capita to CPIND shocks increases as the exposure increases. An exogenous one standard deviation increase in commodity prices results in an increase in real per capita GDP of 0.08 standard deviations in panel (a) to 0.2 in panel (b).

\section{Sectoral regression results}

This section investigates the impact that resource booms have on the sectoral structure of resource-rich, low-income economies. The aim here is to test the hypothesis that resource booms lead to a surge in demand for non-tradables and so a re-allocation of economic activity away from more exportable sectors. Whether this is due to a simple spending effect or a combination of this and a real exchange rate effect will be investigated further in the following section.

I present the results from estimating the SUR fixed effects model in Eq. (6). The block recursive orthogonalised structural shocks for the commodity price index $\left(\varepsilon_{\text {CPINDi,t }}\right)$ from the panel-VAR model in the previous section are included as a regressor in the model with up to three lags. The dependent variable $\left(\mathrm{y}_{\mathrm{i}, \mathrm{t}, \mathrm{j}}\right)$ is the share of real value-added in sector $j$ of country $i$ in year $t$ in total real value-added. The commodity shock variable is scaled by its standard deviation, and so the coefficient estimates show the effect of an exogenous commodity price shock equivalent to one standard

\footnotetext{
23 We use data from the IMF's Annual Report on Exchange Arrangements and Exchange Restrictions (AREAER) database to classify countries. I omit countries whose exchange rate regimes that fall between the fully flexible or hard fix regimes.

${ }^{24}$ The reason for this is that these countries tend to be large OPEC members, and thus not representative of the small open developing economy.
} 
deviation, or a $17.7 \%$ increase. I cluster the standard errors by country, to account for autocorrelation, and year since the treatment, the price shocks, are aggregated at the country level.

Table 2 below presents the results from estimating the model using data on real value-added from the UN National Accounts database. This data breaks total value-added into seven sectoral categories which correspond roughly to the ISIC 1-digit codes. Columns 1-7 present the results of the model for each sector. The sectors are:
1. Agriculture, hunting, forestry, fishing (ISIC A-B) (agric)
2. Mining, Utilities (ISIC C-E) ( $\mathrm{min}$ )
3. Manufacturing (ISIC D) (manuf)
4. Construction (ISIC F) (constr)
5. Wholesale, retail trade, restaurants and hotels (ISIC G-H) (whole)
6. Transport, storage and communication (ISIC I) (trans)
7. Other Activities (ISIC J-P) (other)

The first point to note is the slight reduction in sample size, compared to the panel-VAR, for the various regressions at the 1digit sectoral level. This is due to missing data on value-added at the sectoral level for some countries included in the analysis. The estimates for real value-added cover 30 countries with around 16 years of data for each, giving 570 observations in total.

Positive commodity price movements are associated with contractions in the share of value added in the manufacturing sector, expansions in the transport and other ${ }^{25}$ sectors, but no effect on agriculture. A one standard deviation, or $17.7 \%$, exogenous increase in the country specific commodity price index results in an immediate reduction in the manufacturing sector of around 17 percentage points (pp). The share of value-added in the transport sector increases by $0.10 \mathrm{pp}$ immediately, and a $0.13 \mathrm{pp}$ after two years, whilst the share of value-added in the other sectors, which consists of a number of non-tradable goods and services, increases by around and $0.26 \mathrm{pp}$ after a year or two. Interestingly, the mining sector also contract, albeit after two to three years.

These results lend support to previous empirical findings of a 'de-industrialisation' effect of resource booms in low-income countries. The sectors that appear to benefit most from commodity booms are transportation, finance, real estate and public administration. This may be due to the complementaries that exist between these sectors and the natural resource sectors in low-income countries.

The manufacturing sector as a whole, which is typically thought of as a tradable sector suffers. This may be due to a combination of the 'resource movement' and 'spending effect' channels, in which the tradable nature of manufacturing output leaves the sector susceptible to de-industrialisation pressures following a resource boom. I explore one of the channels through which this de-industrialisation effect may operate in the following section; namely, the Dutch disease.

Because national level control variables on the right hand side of Eq. (6) may be endogenous to sectoral value-added, I have reestimated the SUR models excluding them as a robustness check. The results are presented in Table 5 in Appendix A. There are some small, but ultimately inconsequential, changes to the results. The negative effect of shocks on manufacturing increases to $-0.19 \mathrm{pp}$. Finally, I exclude OPEC members from the sample and re-estimate the sectoral regression. The results are in Table 6 in Appendix A.

\footnotetext{
25 The other category includes: financial intermediation(ISICJ); real estate, renting and business activities (ISIC K); public administration and defence (ISIC L); compulsory social security (ISIC M); education (ISIC N); health and social work (ISIC O); other community, social and personal service activities (ISIC P); and, private households
} with employed persons (ISIC Q).
Again, the results do not change much, although the effect on manufacturing is increased to $-0.22 \mathrm{pp}$. This is consistent with the earlier result that OPEC members appear to see larger macroeconomic responses to commodity price shocks.

\section{The Dutch disease mechanism}

So far the results have shown that whilst resource booms are associated with higher levels of income growth, government spending and investment over the short-run, they also lead to significant re-allocation of economic activity away from tradable sectors. This section explores the possibility of a Dutch disease mechanism at work, in which the real exchange rate appreciates following resource booms thus leading to de-industrialisation. A formal exposition of this link was first presented by Corden and Neary (1982) who argue that resource booms lead to (a) increasing domestic income levels and so an expansion in the demand for non-tradable goods and services, that is a spending channel, and (b) a movement of resources, particularly labour, out of the tradable or exportable sector and into the nontradable sector, that is a resource movement channel. Both of these channels would lead to an appreciation of the real exchange rate as the price of non-tradables increases relative to tradables to clear the domestic market. This section prevents evidence that the contraction in manufacturing presented in the previous section does indeed operate through an exchange rate channel.

The approach taken here is relatively straightforward. I regress the share of manufacturing real value-added in total value-added on a measure of the real exchange rate. The key step is to instrument for changes in competitiveness using the orthogonal commodity price shock variable from the block recursive panel-VAR model. I use this to test whether the de-industrialisation effect of resource booms operates through a real exchange rate channel.

Following Rodrik (2008), I construct a measure of the real exchange rate $(e)$ using data on nominal exchange rates $(E)$ and purchasing power parity conversion factors $(P P P)$, both from the Penn World Tables (PWT) version 6.2 as follows:

$\ln \left(\mathrm{e}_{\mathrm{i}, \mathrm{t}}\right)=\ln \left(\frac{\mathrm{E}_{\mathrm{i}, \mathrm{t}}}{\mathrm{PPP}_{\mathrm{i}, \mathrm{t}}}\right)$

A key issue here is that as countries develop, and income levels rise, there are natural appreciation pressures on the real exchange rate. This is known as the Balassa-Samuelson effect ${ }^{26}$ and is well documented in the literature. I control for this effect by including national level regressors, including real per capita GDP. I estimate the following equation using two-stage least squares (2SLS) and general method of moments (GMM):

$$
\begin{aligned}
& \text { rva_sharemanuf }_{i, t}=\alpha+\beta_{1} G_{i, t}+\beta_{2} I_{i, t}+\beta_{3} I N F L_{i, t} \\
& \quad+\beta_{4} R_{\text {RDPPC }}{ }_{i, t}+\beta_{5} \text { rva_sharemanuf_ini } i_{i, t} \\
& +\beta_{6} R E R_{i, t}+f_{i}+n_{t}+\varepsilon_{i, t}
\end{aligned}
$$

where rva_sharemanuf $f_{i, t}$ is the share of real value i added in total value-added in country $i$ in year $t, f_{i}$ and $n_{t}$ are country and year fixed effects, G, I, INFL and RGDPPC are the country level control variables as before, and $R E R_{i, t}$ is the log of the real exchange rate, instrumented for using the commodity price shock variable $\left(\mathrm{CSHOCK}_{i, t}\right)$, the inflation rate $\left(I N F L_{i, t}\right)$ and $\log$ of real per capita $\operatorname{GDP}\left(R G D P P C_{i, t}\right)$ to account for the Balassa-Samuelson effect.

The results are presented in Table 3 below. In column (1) I exclude all national level controls (G, I, INFL, RGDPPC) in the main

\footnotetext{
${ }^{26}$ The Balasssa-Smuelson effect is the observation that richer countries have systematically higher consumer prices and so more appreciated real exchange rates.
} 
Table 2

SUR model-all sectors.

\begin{tabular}{|c|c|c|c|c|c|c|c|}
\hline Variables & $\begin{array}{l}\text { (1) } \\
\text { Agriculture }\end{array}$ & $\begin{array}{l}(2) \\
\text { Construction }\end{array}$ & $\begin{array}{l}\text { (3) } \\
\text { Manufactures }\end{array}$ & $\begin{array}{l}(4) \\
\text { Minerals }\end{array}$ & $\begin{array}{l}(5) \\
\text { Transport }\end{array}$ & $\begin{array}{l}\text { (6) } \\
\text { Wholesale }\end{array}$ & $\begin{array}{l}\text { (7) } \\
\text { Other }\end{array}$ \\
\hline Log gov expenditure & $\begin{array}{l}-0.423 \\
(-1.572)\end{array}$ & $\begin{array}{l}-0.113 \\
(-1.482)\end{array}$ & $\begin{array}{l}-0.469^{* * * *} \\
(-3.350)\end{array}$ & $\begin{array}{l}-0.361 \\
(-1.077)\end{array}$ & $\begin{array}{l}0.246^{*} \\
(-1.915)\end{array}$ & $\begin{array}{l}-0.0882 \\
(-0.540)\end{array}$ & $\begin{array}{l}0.708^{* * *} \\
(-4.037)\end{array}$ \\
\hline Log gross capital formation & $\begin{array}{l}-0.331 \\
(-0.791)\end{array}$ & $\begin{array}{l}1.883^{* * *} \\
(-8.313)\end{array}$ & $\begin{array}{l}-1.045^{* * *} \\
(-4.612)\end{array}$ & $\begin{array}{l}-0.0307 \\
(-0.0515)\end{array}$ & $\begin{array}{l}-0.386^{* *} \\
(-2.217)\end{array}$ & $\begin{array}{l}-0.242 \\
(-0.708)\end{array}$ & $\begin{array}{l}0.0669 \\
(-0.199)\end{array}$ \\
\hline Deflator & $\begin{array}{l}-0.000264 \\
(-0.819)\end{array}$ & $\begin{array}{l}-0.000174^{* *} \\
(-2.382)\end{array}$ & $\begin{array}{l}0.000315^{*} \\
(-1.865)\end{array}$ & $\begin{array}{l}-0.000172 \\
(-0.681)\end{array}$ & $\begin{array}{l}-0.000123 \\
(-0.337)\end{array}$ & $\begin{array}{l}0.000188 \\
(-1.084)\end{array}$ & $\begin{array}{l}0.000437^{* * *} \\
(-3.125)\end{array}$ \\
\hline Log real GDP per capita & $\begin{array}{l}-6.899^{* * *} \\
(-5.958)\end{array}$ & $\begin{array}{l}-1.476^{* * *} \\
(-3.694)\end{array}$ & $\begin{array}{l}4.712^{* * *} \\
(-5.901)\end{array}$ & $\begin{array}{l}12.43^{* * *} \\
(-5.317)\end{array}$ & $\begin{array}{l}-0.195 \\
(-0.380)\end{array}$ & $\begin{array}{l}0.397 \\
(-0.513)\end{array}$ & $\begin{array}{l}-6.432^{* * *} \\
(-4.124)\end{array}$ \\
\hline Commodity shock from PVAR (cshock) & $\begin{array}{l}-0.0183 \\
(-0.190)\end{array}$ & $\begin{array}{l}0.0217 \\
(-0.6)\end{array}$ & $\begin{array}{l}-0.172^{* *} \\
(-2.070)\end{array}$ & $\begin{array}{l}0.0107 \\
(-0.0535)\end{array}$ & $\begin{array}{l}0.0962^{* *} \\
(-2.275)\end{array}$ & $\begin{array}{l}0.0541 \\
(-0.852)\end{array}$ & $\begin{array}{l}0.0707 \\
(-0.595)\end{array}$ \\
\hline L.cshock & $\begin{array}{l}-0.0978 \\
(-1.085)\end{array}$ & $\begin{array}{l}0.0391 \\
(-1.082)\end{array}$ & $\begin{array}{l}-0.0943 \\
(-1.161)\end{array}$ & $\begin{array}{l}-0.285 \\
(-1.419)\end{array}$ & $\begin{array}{l}0.132^{* * * *} \\
(-2.824)\end{array}$ & $\begin{array}{l}0.0926 \\
(-1.466)\end{array}$ & $\begin{array}{l}0.255^{* *} \\
(-2.232)\end{array}$ \\
\hline L2.cshock & $\begin{array}{l}0.0154 \\
(-0.194)\end{array}$ & $\begin{array}{l}-0.0212 \\
(-0.574)\end{array}$ & $\begin{array}{l}-0.0717 \\
(-0.954)\end{array}$ & $\begin{array}{l}-0.397^{* *} \\
(-2.126)\end{array}$ & $\begin{array}{l}0.123^{* * *} \\
(-2.863)\end{array}$ & $\begin{array}{l}0.0902 \\
(-1.42)\end{array}$ & $\begin{array}{l}0.252^{* *} \\
(-2.113)\end{array}$ \\
\hline L3.cshock & $\begin{array}{l}0.00777 \\
(-0.0907)\end{array}$ & $\begin{array}{l}0.0461 \\
(-1.299)\end{array}$ & $\begin{array}{l}0.0135 \\
(-0.175)\end{array}$ & $\begin{array}{l}-0.394^{* *} \\
(-2.016)\end{array}$ & $\begin{array}{l}0.0292 \\
(-0.719)\end{array}$ & $\begin{array}{l}0.0687 \\
(-1.105)\end{array}$ & $\begin{array}{l}0.176 \\
(-1.356)\end{array}$ \\
\hline Initial real VA share agriculture & $\begin{array}{l}0.569^{* * *} \\
(-6.444)\end{array}$ & & & & & & \\
\hline Initial real VA share construction & & $\begin{array}{l}-0.0526 \\
(-1.725)\end{array}$ & & & & & \\
\hline Initial real VA share manufacturing & & & $\begin{array}{l}0.489^{* * *} \\
(-18.76)\end{array}$ & & & & \\
\hline Initial real VA share mining & & & & $\begin{array}{l}0.461^{* * *} \\
(-3.916)\end{array}$ & & & \\
\hline Initial real VA share transport & & & & & $\begin{array}{l}0.851^{* * * *} \\
(-7.471)\end{array}$ & & \\
\hline Initial real VA share wholesale & & & & & & $\begin{array}{l}0.285^{* * *} \\
(-3.8)\end{array}$ & \\
\hline Initial real VA share other & & & & & & & $\begin{array}{l}0.277^{* * *} \\
(-2.87)\end{array}$ \\
\hline Observations & 577 & 577 & 577 & 577 & 577 & 577 & 577 \\
\hline
\end{tabular}

Robust z-statistics in parentheses.

Shock= cshock; country and year fixed effects included; low-income, resource-rich countries; standard errors clustered by country and year.

*** $\mathrm{p}<0.01$.

** $p<0.05$.

* $\mathrm{p}<0.1$.

Table 3

IV regression-real exchange rate channel.

\begin{tabular}{|c|c|c|c|}
\hline Variables & Manufacturing real value-added share & Manufacturing real value-added share & Manufacturing real value-added share \\
\hline \multirow[t]{2}{*}{ log real exchange rate } & $8.181^{* * *}$ & $5.086^{* *}$ & $4.899^{* *}$ \\
\hline & -3.462 & -2.386 & -2.231 \\
\hline \multirow[t]{2}{*}{ initial real VA share manufacturing } & $2.094^{* * *}$ & $1.729^{* * *}$ & $1.683^{* * *}$ \\
\hline & -6.027 & -3.917 & -3.46 \\
\hline \multirow[t]{2}{*}{ log gov expenditure } & & 0.111 & 0.0826 \\
\hline & & -0.615 & -0.441 \\
\hline \multirow[t]{2}{*}{ log gross capital formation } & & -0.34 & -0.356 \\
\hline & & $(-1.180)$ & $(-1.255)$ \\
\hline \multirow[t]{2}{*}{ deflator } & & -0.000256 & -0.000271 \\
\hline & & $(-0.803)$ & $(-1.457)$ \\
\hline \multirow[t]{2}{*}{ log real GDP per capita } & & 1.537 & 1.819 \\
\hline & & -1.427 & -1.582 \\
\hline Constant & $\begin{array}{l}-14.67^{* * *} \\
(-4.203)\end{array}$ & $\begin{array}{l}-15.29^{*} \\
(-1.675)\end{array}$ & $\begin{array}{l}-15.64 \\
(-1.608)\end{array}$ \\
\hline Observations & 580 & 580 & 580 \\
\hline R-squared & 0.9 & 0.932 & 0.933 \\
\hline Estimation & 2SLS & 2SLS & GMM \\
\hline Controls & NO & YES & YES \\
\hline Year and country FE & YES & YES & YES \\
\hline
\end{tabular}

Robust z-statistics in parentheses.

*** $\mathrm{p}<0.01$.

** $\mathrm{p}<0.05$.

* $\mathrm{p}<0.1$.

Table 4

Nigeria projections vs outturn.

\begin{tabular}{|c|c|c|c|c|c|c|c|}
\hline \multirow[t]{2}{*}{ Period } & \multicolumn{4}{|c|}{ Simulation } & \multicolumn{3}{|l|}{ Actual outturn } \\
\hline & RGDPPC & G & I & Year & Real per capita GDP & Real inv & Real gov exp \\
\hline 0 & - & - & - & 2014 & 3.5 & 12.7 & 0.2 \\
\hline 1 & -0.4 & -20.3 & -7.2 & 2015 & -0.1 & -5.9 & -3.8 \\
\hline
\end{tabular}


equation and estimate the model using 2SLS. Column (2) includes national level controls and column (3) re-estimates this model using GMM. In each case, the real exchange rate variable is instrumented for using commodity price shocks. All three models agree in the direction of the effect: a fall in the real exchange rate (i.e. an appreciation) caused by commodity positive price shocks results in a reduction in the share of manufacturing value-added of between 5 and 8 percentage points.

\section{Nigeria and the oil price collapse-a case study}

This paper has argued that exogenous commodity price movements can be used as a proxy for resource shocks in resource-rich, low-income countries. Over the short run, booms tend to lead to modest increases in growth, government expenditure and investment in these countries. However, they also result in significant short run structural transformation away from 'exportable' sectors towards more 'non-tradable' activities; perhaps as a result of movements in the real exchange rate that undermine competitiveness.

But how large are these effects in practice. To put these results into context, this section analyses the recent oil price collapse at the beginning of 2015. I focus specifically on Nigeria as a major oil exporter in my sample, and construct the implied change in the country specific price index after the shock. I calculate the impulse effect on growth, government spending and investment as a result of the shock, using the results from the block recursive identification scheme.

The first step is to identify how the recent oil price collapse compares to the normal variation in the data? The UK Brent Crude Price fell from 101.8 to 53.9 USD per barrel in the 6 months between $2014 q 3$ and in $2015 q 1$, equivalent to a $47.1 \%$ collapse. Over roughly the same period, rich country GDP growth slowed to $1.8 \%$ and the US Libor rate fell by $19.6 \%$. The slowdown of aggregate demand and looser financial conditions account for around 18 percentage points (pp) of the oil price collapse. I treat the remaining $29 \%$ drop in oil prices as the exogenous shock. I also assume that any movement in the oil price is exactly reflected in the movement of its reserve-weighted commodity price index. ${ }^{27}$

Table 4 reports the results of simulating a one period exogenous collapse in the price of oil of $29 \%$ for Nigeria, equivalent to a 1.6 standard deviation shock. As a result of the oil price shock, Nigeria suffers a contraction of real per capita GDP of $0.4 \%$ in the same period; government spending and investment shrink by $20.3 \%$ and $7.2 \%$ respectively. Table 4 also reports actual data for the Nigerian economy in 2014 and 2015 based on IMF WEO data. Between 2014 and 2015 real per capita GDP shrunk by $0.1 \%$, government spending by $-5.9 \%$ and investment by $3.8 \%$. Whilst the direction of movement of the key variables are in line with the model predictions, the magnitudes of the simulated effects are somewhat larger than the actual data suggests.

\section{Conclusion}

Over the past decade extractive industries in Africa have emerged as a powerful engine of economic growth, driven in part by surging demand for natural resources in emerging markets. The continent's hydrocarbon and mineral potential has been a powerful magnet for foreign investment with new exploration revealing vast reserves, particularly in sub-Saharan Africa. Recent discoveries of natural gas in Mozambique and Tanzania, and oil in Ghana, Uganda and Madagascar are cases in point. The challenge facing the region now is how to transform these temporary resource windfalls into permanent economic and human development successes.

This paper presents an empirical investigation of the dynamic macroeconomic response of resource-rich, low-income countries to global commodity price fluctuations; specifically minerals and hydrocarbons. I provide new evidence on the relationship between resource booms, economic growth and structural transformation in these economies. The endogeneity problems inherent in the cross-country literature on resource booms make it challenging to identify a causal effect of resource wealth on economic development. This paper improves upon previous estimates by identifying exogenous, supply driven commodity price shocks for resource-rich, low-income economies. It then uses these shocks to investigate the potential Dutch disease effects of resource booms at the sectoral level.

I use a panel vector auto regression (or panel-VAR) approach to identify exogenous shocks to global commodity prices and to estimate the dynamic, short-run response of these shocks on economic growth, government spending and domestic investment. The potential for short-term Dutch disease effects are investigated using a seemingly unrelated regression (SUR) framework. Finally, I present preliminary evidence that the channel through which the link between resource booms and sectoral growth operates is the real exchange rate.

Focusing on resource-rich, low-income economies the results suggest that positive commodity price shocks raise per capita income levels, investment and government spending in the short to medium term, as well as lowering inflation. These effects, however, are quantitatively small, suggesting that commodity price movements alone may be less important in explaining the volatility of low-income country growth than other explanations, such as demand and productivity shocks. Resource booms also result in significant re-structuring of the domestic economy. I show that an empirically robust link exists between resource wealth and the relative growth of tradable or exportable industries. The share of value-added in non-tradable goods and services, such as transport, finance and real estate, expands in response to positive resource shocks whilst value-added in manufacturing contracts. This mechanism appears to operate through the real exchange rate, with resource shocks leading to appreciations which in turn cause a restructuring of the domestic economy. The effects are larger for less developed countries, economies with fixed exchange rate regimes and those that are more dependent on commodity exports.

\section{Appendix A.}

See Figs. 4-12 and Tables 5 and 6.

\footnotetext{
27 We believe this is a sensible assumption as oil reserves make up almost all of Nigeria's natural resource reserves. Nigeria produces a small amount of natural gas
} but reserves are insignificant compared to oil. 
Table 5

SUR model - all sectors - no controls.

\begin{tabular}{|c|c|c|c|c|c|c|c|}
\hline Variables & $\begin{array}{l}\text { (1) } \\
\text { Agriculture }\end{array}$ & $\begin{array}{l}(2) \\
\text { Construction }\end{array}$ & $\begin{array}{l}\text { (3) } \\
\text { Manufactures }\end{array}$ & $\begin{array}{l}(4) \\
\text { Minerals }\end{array}$ & $\begin{array}{l}(5) \\
\text { Transport }\end{array}$ & $\begin{array}{l}(6) \\
\text { Wholesale }\end{array}$ & $\begin{array}{l}\text { (7) } \\
\text { Other }\end{array}$ \\
\hline Commodity shock from PVAR (cshock) & $\begin{array}{l}0.0786 \\
(-0.779)\end{array}$ & $\begin{array}{l}-0.0191 \\
(-0.396)\end{array}$ & $\begin{array}{l}-0.186^{* *} \\
(-2.107)\end{array}$ & $\begin{array}{l}-0.13 \\
(-0.629)\end{array}$ & $\begin{array}{l}0.106^{* *} \\
(-2.476)\end{array}$ & $\begin{array}{l}0.0593 \\
(-0.927)\end{array}$ & $\begin{array}{l}0.135 \\
(-1.081)\end{array}$ \\
\hline L.cshock & $\begin{array}{l}-0.0913 \\
(-0.882)\end{array}$ & $\begin{array}{l}0.0188 \\
(-0.44)\end{array}$ & $\begin{array}{l}-0.0955 \\
(-1.078)\end{array}$ & $\begin{array}{l}-0.301 \\
(-1.459)\end{array}$ & $\begin{array}{l}0.140 \\
(-2.926)\end{array}$ & $\begin{array}{l}0.0926 \\
(-1.458)\end{array}$ & $\begin{array}{l}0.268^{* *} \\
(-2.256)\end{array}$ \\
\hline L2.cshock & $\begin{array}{l}0.0325 \\
(-0.337)\end{array}$ & $\begin{array}{l}-0.0346 \\
(-0.883)\end{array}$ & $\begin{array}{l}-0.0745 \\
(-0.943)\end{array}$ & $\begin{array}{l}-0.429^{* *} \\
(-2.170)\end{array}$ & $\begin{array}{l}0.127^{* * *} \\
(-2.945)\end{array}$ & $\begin{array}{l}0.0918 \\
(-1.438)\end{array}$ & $\begin{array}{l}0.272^{* *} \\
(-2.284)\end{array}$ \\
\hline L3.cshock & $\begin{array}{l}0.0136 \\
(-0.135)\end{array}$ & $\begin{array}{l}0.00336 \\
(-0.0884)\end{array}$ & $\begin{array}{l}0.0355 \\
(-0.439)\end{array}$ & $\begin{array}{l}-0.392^{*} \\
(-1.830)\end{array}$ & $\begin{array}{l}0.0391 \\
(-0.945)\end{array}$ & $\begin{array}{l}0.0734 \\
(-1.171)\end{array}$ & $\begin{array}{l}0.175 \\
(-1.309)\end{array}$ \\
\hline Initial real VA share agriculture & $\begin{array}{l}1.153^{* * * *} \\
(-48.63)\end{array}$ & & & & & & \\
\hline Initial real VA share construction & & $\begin{array}{l}-0.193^{* * *} \\
(-11.07)\end{array}$ & & & & & \\
\hline Initial real VA share manufacturing & & & $\begin{array}{l}0.278^{* * *} \\
(-18.01)\end{array}$ & & & & \\
\hline Initial real VA share mining & & & & $\begin{array}{l}0.831^{\text {**** }} \\
(-18.4)\end{array}$ & & & \\
\hline Initial real VA share transport & & & & & $\begin{array}{l}0.843^{* * *} \\
(-43.68)\end{array}$ & & \\
\hline Initial real VA share wholesale & & & & & & $\begin{array}{l}-0.0151 \\
(-0.304)\end{array}$ & \\
\hline Initial real VA share other & & & & & & & $\begin{array}{l}0.566^{* * *} \\
(-9.458)\end{array}$ \\
\hline Observations & 577 & 577 & 577 & 577 & 577 & 577 & 577 \\
\hline
\end{tabular}

Robust z-statistics in parentheses

Shock= cshock; country and year fixed effects included; low-income, resource-rich countries; standard errors clustered by country and year.

*** $\mathrm{p}<0.01$.

** $\mathrm{p}<0.05$.

* $\mathrm{p}<0.1$.

Table 6

SUR model - all sectors - national controls, no OPEC.

\begin{tabular}{|c|c|c|c|c|c|c|c|}
\hline Variables & $\begin{array}{l}\text { (1) } \\
\text { Agriculture }\end{array}$ & $\begin{array}{l}\text { (2) } \\
\text { Construction }\end{array}$ & $\begin{array}{l}\text { (3) } \\
\text { Manufactures }\end{array}$ & $\begin{array}{l}(4) \\
\text { Minerals }\end{array}$ & $\begin{array}{l}\text { (5) } \\
\text { Transport }\end{array}$ & $\begin{array}{l}(6) \\
\text { Wholesale }\end{array}$ & $\begin{array}{l}\text { (7) } \\
\text { Other }\end{array}$ \\
\hline Log gov expenditure & $\begin{array}{l}-0.472 \\
(-1.539)\end{array}$ & $\begin{array}{l}-0.156^{*} \\
(-1.841)\end{array}$ & $\begin{array}{l}-0.711^{* * *} \\
(-4.677)\end{array}$ & $\begin{array}{l}-0.121 \\
(-0.343)\end{array}$ & $\begin{array}{l}0.342^{* *} \\
(-2.387)\end{array}$ & $\begin{array}{l}-0.0179 \\
(-0.0988)\end{array}$ & $\begin{array}{l}0.636^{* * *} \\
(-3.352)\end{array}$ \\
\hline Log gross capital formation & $\begin{array}{l}-0.318 \\
(-0.713)\end{array}$ & $\begin{array}{l}1.883^{* * *} \\
(-7.88)\end{array}$ & $\begin{array}{l}-0.875^{* * *} \\
(-3.741)\end{array}$ & $\begin{array}{l}-0.692 \\
(-1.139)\end{array}$ & $\begin{array}{l}-0.293 \\
(-1.609)\end{array}$ & $\begin{array}{l}-0.315 \\
(-0.853)\end{array}$ & $\begin{array}{l}0.27 \\
(-0.761)\end{array}$ \\
\hline Deflator & $\begin{array}{l}-0.00029 \\
(-0.861)\end{array}$ & $\begin{array}{l}-0.000186^{* *} \\
(-2.520)\end{array}$ & $\begin{array}{l}0.000326^{* *} \\
(-2.089)\end{array}$ & $\begin{array}{l}-0.000171 \\
(-0.741)\end{array}$ & $\begin{array}{l}-0.000171 \\
(-0.497)\end{array}$ & $\begin{array}{l}0.00018 \\
(-0.978)\end{array}$ & $\begin{array}{l}0.000529 \\
(-3.423)\end{array}$ \\
\hline Log real GDP per capita & $\begin{array}{l}-6.762^{* * *} \\
(-4.958)\end{array}$ & $\begin{array}{l}-1.318^{* * *} \\
(-2.949)\end{array}$ & $\begin{array}{l}6.376^{* * *} \\
(-7.767)\end{array}$ & $\begin{array}{l}6.435^{* * *} \\
(-3.502)\end{array}$ & $\begin{array}{l}-1.127^{* *} \\
(-2.006)\end{array}$ & $\begin{array}{l}-0.0671 \\
(-0.0751)\end{array}$ & $\begin{array}{l}-2.837^{* *} \\
(-2.256)\end{array}$ \\
\hline Commodity shock from PVAR (cshock) & $\begin{array}{l}-0.0176 \\
(-0.160)\end{array}$ & $\begin{array}{l}0.0353 \\
(-0.855)\end{array}$ & $\begin{array}{l}-0.221^{* * *} \\
(-2.638)\end{array}$ & $\begin{array}{l}-0.0148 \\
(-0.0714)\end{array}$ & $\begin{array}{l}0.0941^{* *} \\
(-1.97)\end{array}$ & $\begin{array}{l}0.0285 \\
(-0.397)\end{array}$ & $\begin{array}{l}0.13 \\
(-1.287)\end{array}$ \\
\hline L.cshock & $\begin{array}{l}-0.0899 \\
(-0.876)\end{array}$ & $\begin{array}{l}0.0393 \\
(-0.935)\end{array}$ & $\begin{array}{l}-0.106 \\
(-1.346)\end{array}$ & $\begin{array}{l}-0.223 \\
(-1.067)\end{array}$ & $\begin{array}{l}0.135^{* * *} \\
(-2.586)\end{array}$ & $\begin{array}{l}0.0439 \\
(-0.631)\end{array}$ & $\begin{array}{l}0.244^{* *} \\
(-2.472)\end{array}$ \\
\hline L2.cshock & $\begin{array}{l}0.0119 \\
(-0.13)\end{array}$ & $\begin{array}{l}-0.0181 \\
(-0.416)\end{array}$ & $\begin{array}{l}-0.125 \\
(-1.641)\end{array}$ & $\begin{array}{l}-0.16 \\
(-0.906)\end{array}$ & $\begin{array}{l}0.0988^{* *} \\
(-1.963)\end{array}$ & $\begin{array}{l}0.0616 \\
(-0.867)\end{array}$ & $\begin{array}{l}0.186^{*} \\
(-1.886)\end{array}$ \\
\hline L3.cshock & $\begin{array}{l}0.0324 \\
(-0.331)\end{array}$ & $\begin{array}{l}0.055 \\
(-1.432)\end{array}$ & $\begin{array}{l}0.0143 \\
(-0.192)\end{array}$ & $\begin{array}{l}-0.24 \\
(-1.387)\end{array}$ & $\begin{array}{l}0.0195 \\
(-0.408)\end{array}$ & $\begin{array}{l}0.0332 \\
(-0.503)\end{array}$ & $\begin{array}{l}0.0594 \\
(-0.606)\end{array}$ \\
\hline Initial real VA share agriculture & $\begin{array}{l}0.580^{* * *} \\
(-5.651)\end{array}$ & & & & & & \\
\hline Initial real VA share construction & & $\begin{array}{l}-0.0986^{* *} \\
(-2.301)\end{array}$ & & & & & \\
\hline Initial real VA share manufacturing & & & $\begin{array}{l}0.490^{* * * *} \\
(-17.94)\end{array}$ & & & & \\
\hline Initial real VA share mining & & & & $\begin{array}{l}0.199^{*} \\
(-1.674)\end{array}$ & & & \\
\hline Initial real VA share transport & & & & & $\begin{array}{l}0.643^{* * *} \\
(-5.117)\end{array}$ & & \\
\hline Initial real VA share wholesale & & & & & & $\begin{array}{l}0.312^{* * *} \\
(-3.989)\end{array}$ & \\
\hline Initial real VA share other & & & & & & & $\begin{array}{l}1.071^{* * *} \\
(-7.579)\end{array}$ \\
\hline Observations & 577 & 577 & 577 & 577 & 577 & 577 & 577 \\
\hline
\end{tabular}

Robust z-statistics in parentheses.

Shock = cshock; country and year fixed effects included; low-income, resource-rich countries; standard errors clustered by country and year.

*** $\mathrm{p}<0.01$.

** $\mathrm{p}<0.05$. 


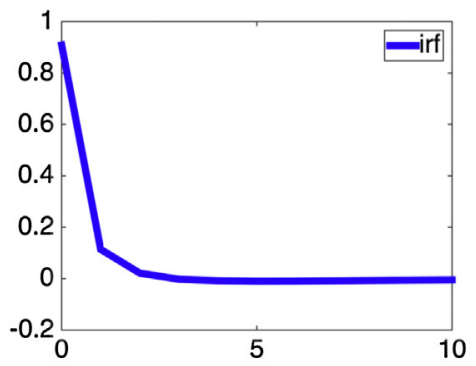

(a) imp: cpind - resp: cpind

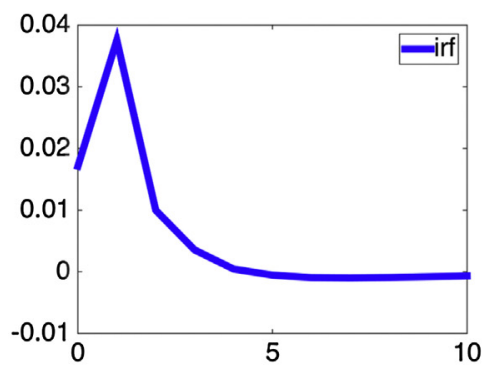

(d) imp: cpind - resp: rgdppc

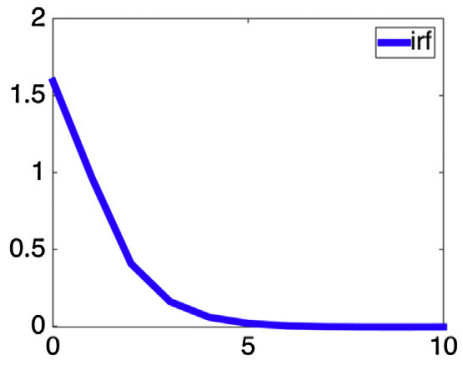

(b) imp: gdph - resp: cpind

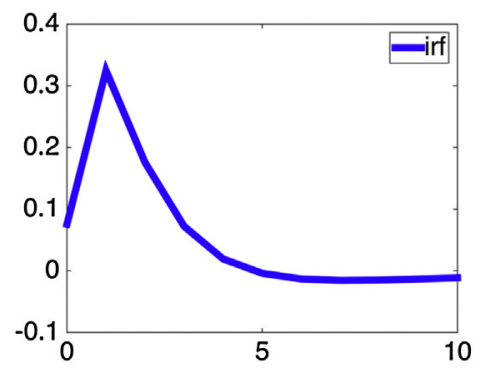

(e) imp: cpind - resp: g

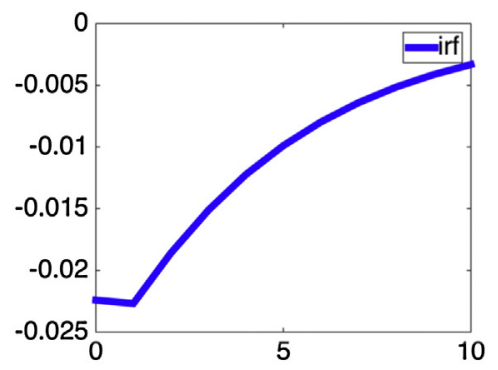

(c) imp: libor - resp: cpind

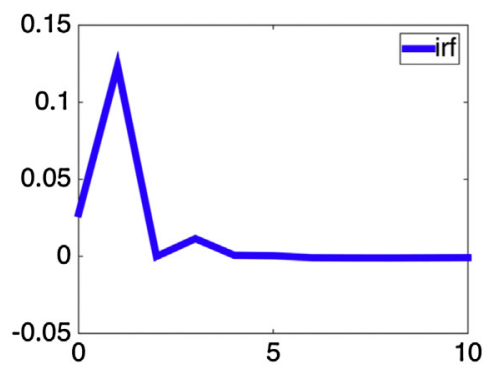

(f) imp: cpind - resp: i

Fig. 4. Panel VAR IRFs - Choleski - no OPEC members.

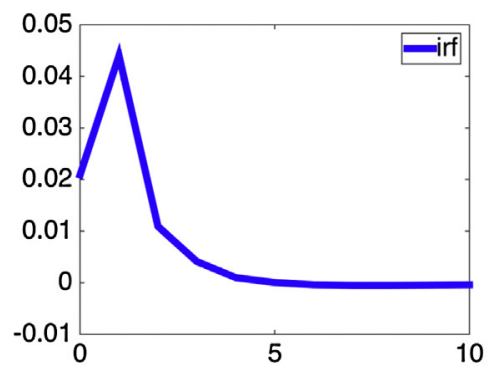

(a) imp: cpind - resp: rgdppc

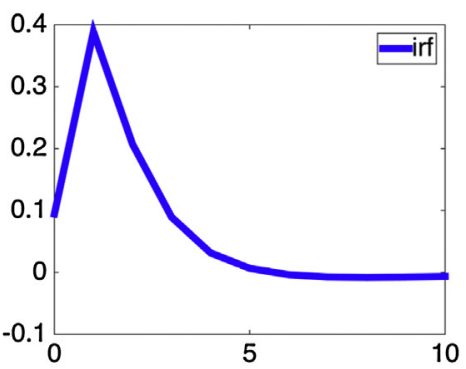

(b) imp: cpind - resp: g

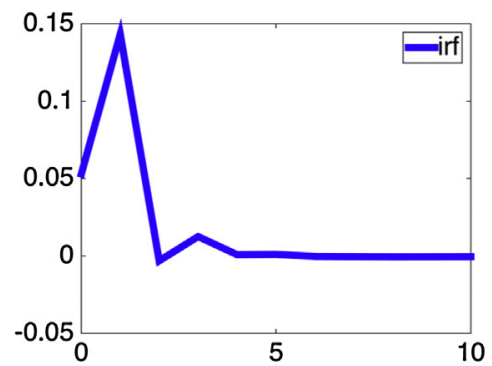

(c) imp: cpind - resp: i

Fig. 5. Panel VAR IRFs - block recursive - no OPEC members. 


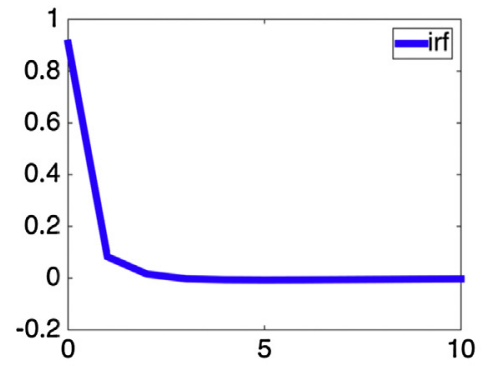

(a) imp: cpind - resp: cpind

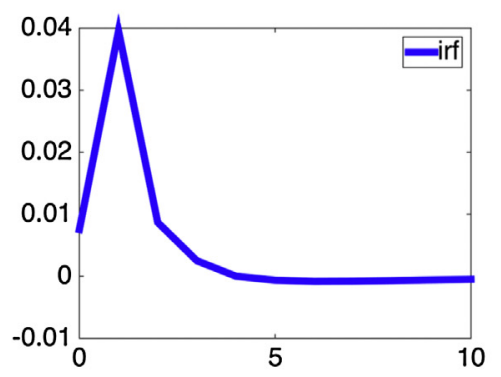

(d) imp: cpind - resp: rgdppc

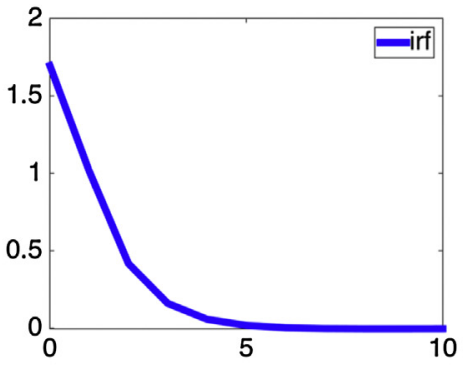

(b) imp: gdph - resp: cpind

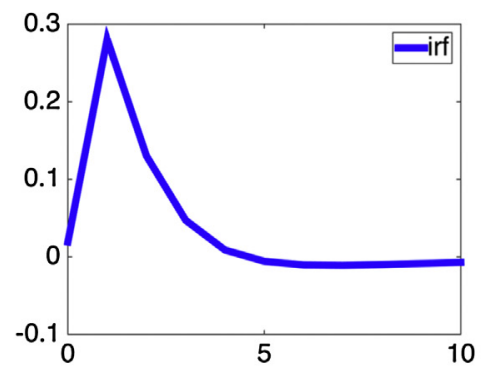

(e) imp: cpind - resp: g

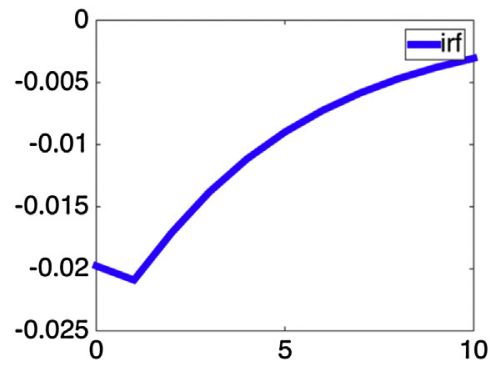

(c) imp: libor - resp: cpind

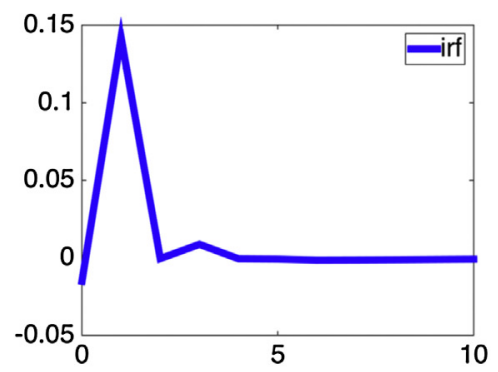

(f) imp: cpind - resp: i

Fig. 6. Panel VAR IRFs - Choleski - low and middle income countries.

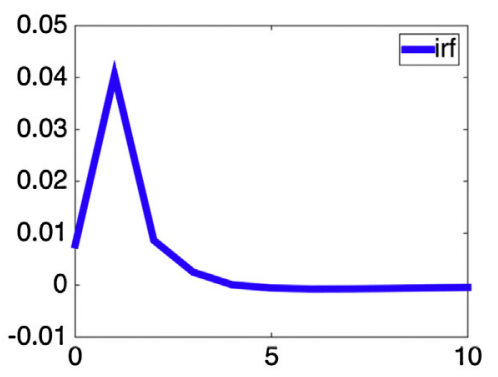

(a) imp: cpind - resp: rgdppc

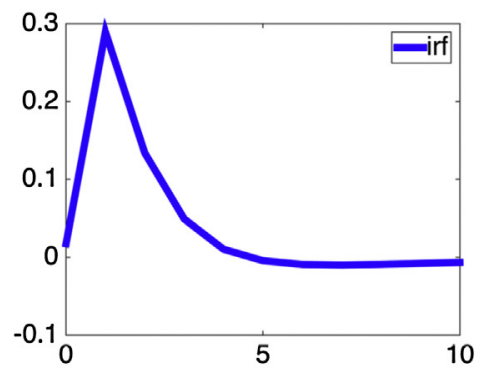

(b) imp: cpind - resp: g

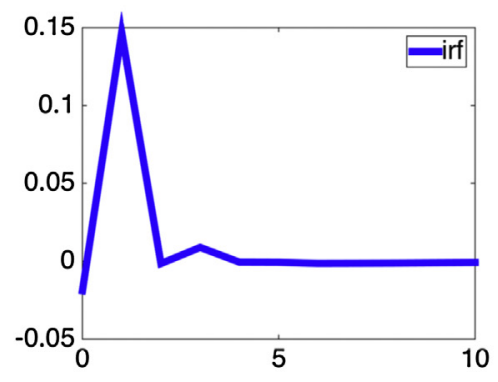

(c) imp: cpind - resp: i

Fig. 7. Panel VAR IRFs - block recursive - low and middle income countries.

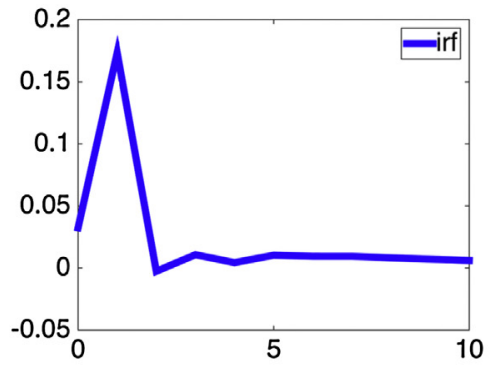

(a) imp: cpind - resp: rgdppc

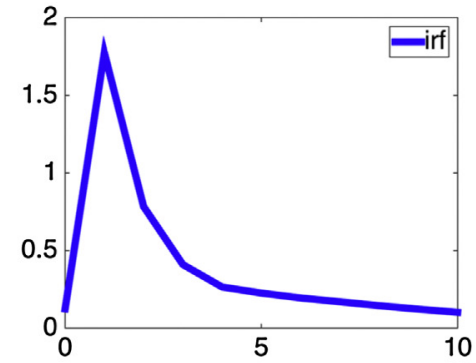

(b) imp: cpind - resp: g

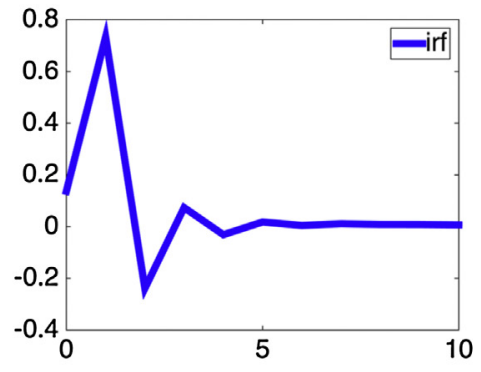

(c) imp: cpind - resp: i

Fig. 8. Panel VAR IRFs - block recursive - fixed exchange rate. 


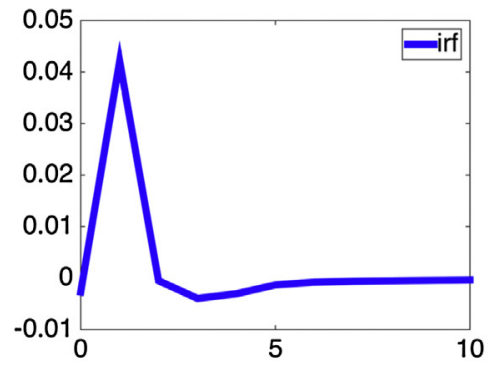

(a) imp: cpind - resp: rgdppc

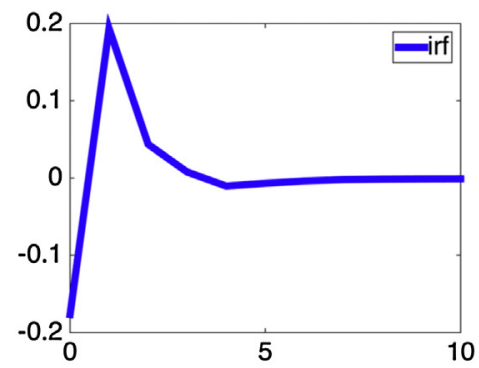

(b) imp: cpind - resp: g

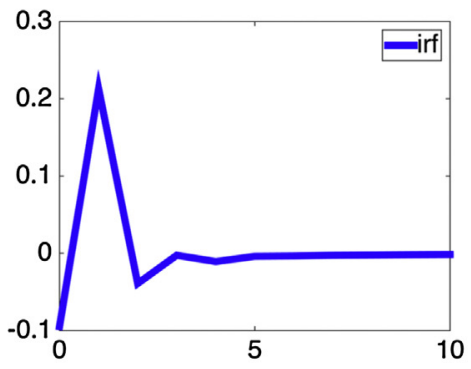

(c) imp: cpind - resp: i

Fig. 9. Panel VAR IRFs - block recursive - flexible exchange rate.

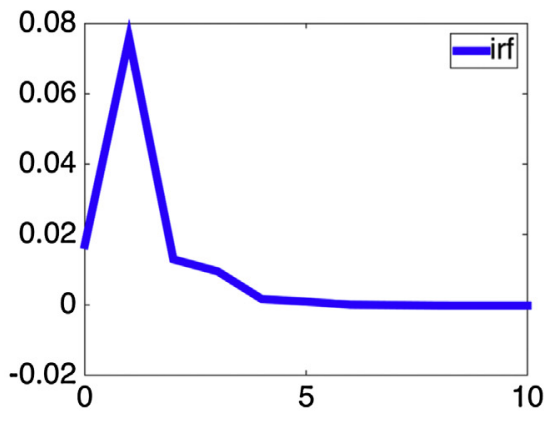

(a) imp: cpind - resp: rgdppc

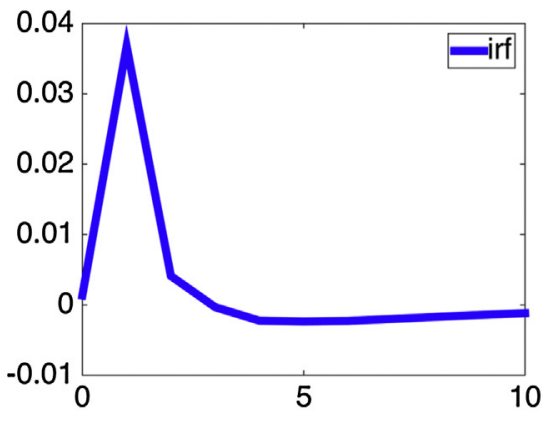

(b) imp: cpind - resp: rgdppc

Fig. 10. Panel VAR IRFs - Choleski - exposure levels.

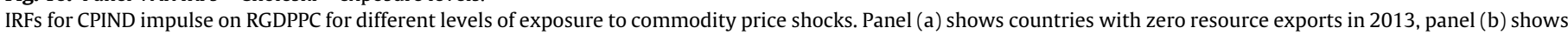
countries with positive resource exports.

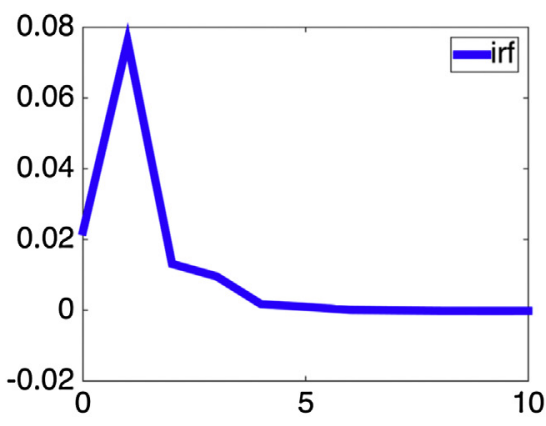

(a) imp: cpind - resp: rgdppc

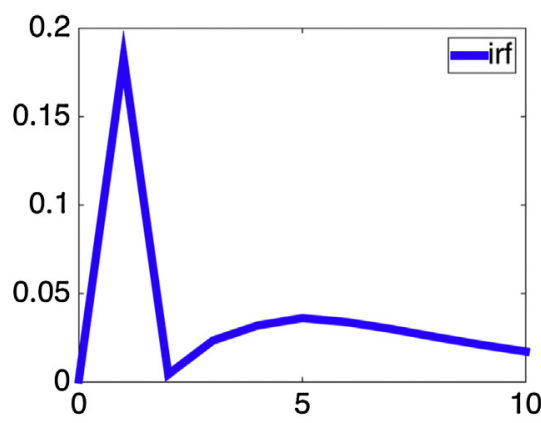

(b) imp: cpind - resp: rgdppc

Fig. 11. Panel VAR IRFs - block recursive - exposure levels.

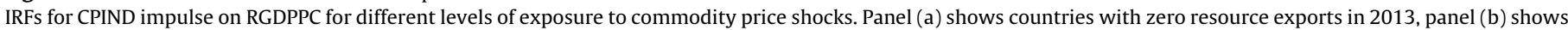
countries with positive resource exports. 

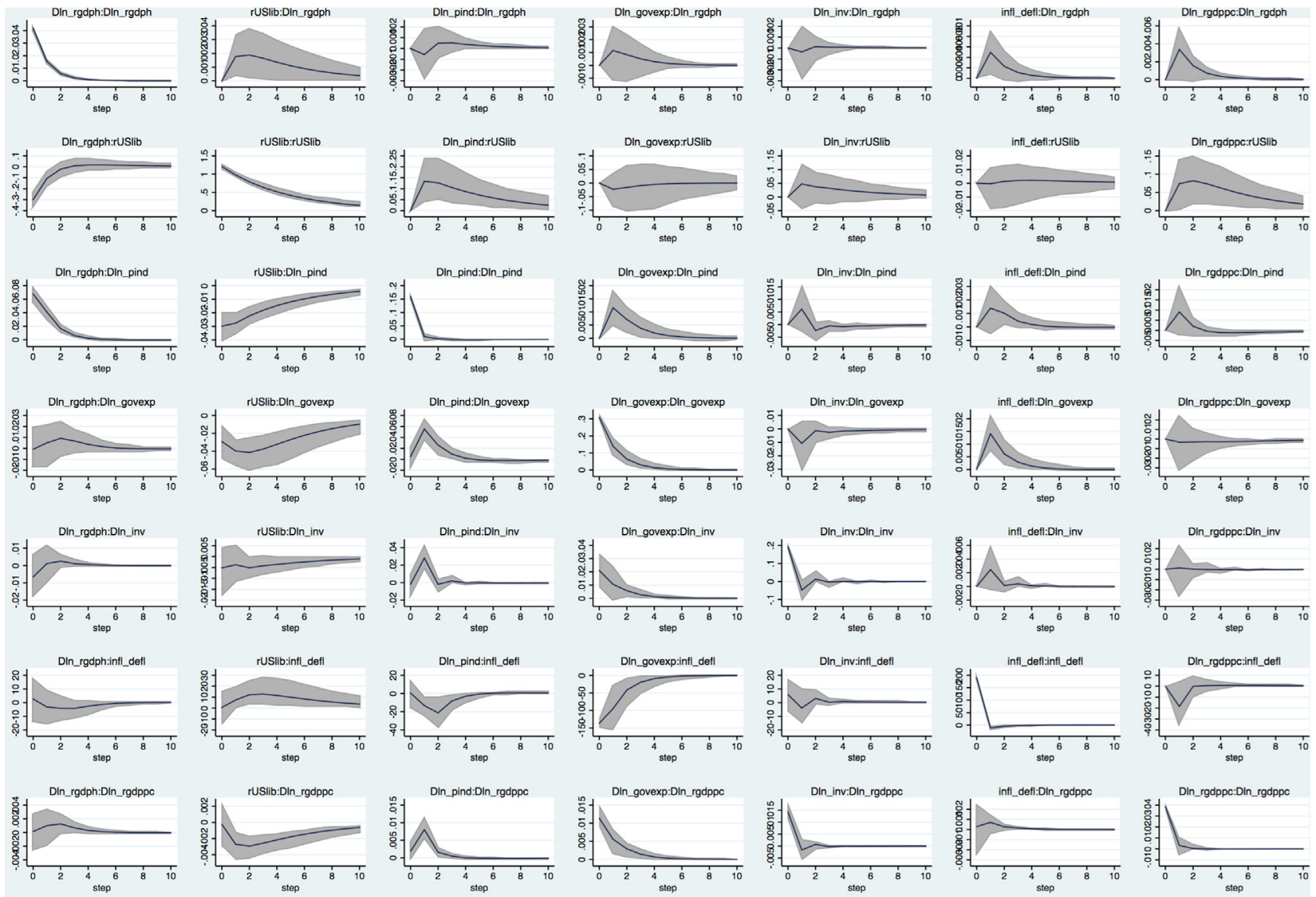

\section{impulse variable: response variable}

Fig. 12. Panel VAR IRFs - Choleski - IRFs with $95 \%$ confidence bands.

IRFs and confidence 95\% intervals are presented before scaling.

\section{References}

Ahmed, S. (2003). Sources of economic fluctuations in Latin America and implications for choice of exchange rate regimes. Journal of Development Economics, 72(1), 181-202.

Arellano, M., \& Bover, O.(1995). Another look at the instrumental variable estimation of error-components models. Journal of Econometrics, 68(1), 29-51.

Broda, C. (2001). Coping with terms-of-trade shocks: Pegs versus floats. American Economic Review, 376-380.

Broda, C. (2004). Coping with terms-of-trade shocks: Pegs versus floats. Journal of International Economics, 63(1), 31-58.

Brunnschweiler, C. N., \& Bulte, E. H. (2008). The resource curse revisited and revised: A tale of paradoxes and red herrings. Journal of Environmental Economics and Management, 55(3), 248-264.

Collier, P. \& Dehn, J. (2001). Aid, shocks, and growth. World Bank Policy Research Working Paper, 2688.

Collier, P., \& Goderis, B. (2012). Commodity prices and growth: An empirical investigation. European Economic Review, 56(6), 1241-1260.

Collier, P., \& Gunning, J. W. (1999). Why has Africa grown slowly? The Journal of Economic Perspectives, 3-22.

Corden, M. W., \& Neary, P. J. (1982). Booming sector and de-industrialisation in a small open economy. The Economic Journal, 825-848.

Deaton, A., \& Miller, R. I. (1996). International commodity prices, macroeconomic performance, and politics in Sub-Saharan Africa. Journal of African Economies, 5(3), 99-192.

Dehn, J. (2000). The effects on growth of commodity price uncertainty and shocks. World Bank Policy Research Working Paper, 2455.

Erten, B., \& Ocampo, J. A. (2013). Super-cycles of the commodity prices since the mid-nineteenth century. World Development, 44, 14-30.

Hamilton, J. D. (2003). What is an oil shock? Journal of Econometrics, 113(2), 363-398.

Heap, A. (2005). China-The engine of a commodities super-cycle. pp. 1-24. New York: Citigroup Smith Barney.

Judson, R. A., \& Owen, A. L. (1999). Estimating dynamic panel data models: A guide for macroeconomists. Economics Letters, 65, 9-15, 1.
Kilian, L. (2008). Exogenous oil supply shocks: How big are they and how much do they matter for the us economy? The Review of Economics and Statistics, 90(2), $216-240$.

Love, I., \& Zicchino, L. (2006). Financial development and dynamic investment behavior: Evidence from panel var. The Quarterly Review of Economics and Finance, 46(2), 190-210.

Manzano, O. \& Rigobon, R. (2001). Resource curse or debt overhang? National Bureau of Economic Research Working Paper, 8390.

Mehlum, H., Moene, K., \& Torvik, R. (2006). Institutions and the resource curse. The Economic Journal, 116(508), 1-20.

Nickell, S. (1981). Biases in dynamic models with fixed effects. Econometrica: Journal of the Econometric, Society, 1417-1426.

Raddatz, C. (2007). Are external shocks responsible for the instability of output in low-income countries? Journal of Development Economics, 84(1), 155-187.

Rajan, R. G., \& Subramanian, A. (2011). Aid, Dutch disease, and manufacturing growth. Journal of Development Economics, 94(1), 106-118.

Rodrik, D. (2008). The real exchange rate and economic growth. Brookings Papers on Economic Activity, 2008(2), 365-412.

Rogers, J. (2004). How anyone can invest profitably in the world's best market. New York: Random House.

Sachs, J. D., \& Warner, A. M. (1995). Natural resource abundance and economic growth. Technical report. National Bureau of Economic Research.

Sachs, J. D., \& Warner, A. M. (1999). The big push, natural resource booms and growth. Journal of Development Economics, 59(1), 43-76.

Uribe, M., \& Yue, V.Z. (2006). Country spreads and emerging countries: Who drives whom? Journal of International Economics, 69(1), 6-36.

Van der Ploeg, F. (2011). Natural resources: Curse or blessing? Journal of Economic Literature, 366-420.

Van der Ploeg, F., \& Poelhekke, S. (2010). The pungent smell of red herrings: Subsoil assets, rents, volatility and the resource curse. Journal of Environmental Economics and Management, 60(1), 44-55. 